\title{
Engrailed-like immunoreactivity in the embryonic ventral nerve cord of the Marbled Crayfish (Marmorkrebs)
}

\author{
Kathia Fabritius-Vilpoux $\cdot$ Sonja Bisch-Knaden · \\ Steffen Harzsch
}

Received: 16 July 2008/ Accepted: 27 October 2008/Published online: 13 November 2008

(C) The Author(s) 2008. This article is published with open access at Springerlink.com

\begin{abstract}
The homeobox transcription factor Engrailed is involved in controlling segmentation during arthropod germ band formation but also in establishing individual neuronal identities during later embryogenesis. In Crustacea, most studies analysing the expression of Engrailed so far have focussed on its function as segment polarity gene. In continuation to these previous studies, we analysed the neuronal expression of the Engrailed protein by immunohistochemistry in the embryonic nerve cord of a parthenogenetic crustacean, the Marbled Crayfish (Marmorkrebs). We paid particular attention to the individual identification of Engrailed expressing putative neuroblasts in the crayfish embryos. Engrailed positive cells in the neuroectoderm were counted, measured and mapped from 38 to $65 \%$ of embryonic development. That way, several Engrailed positive putative neuroblasts and putative neurons were identified. Our findings are compared with earlier studies on Engrailed expression during germ band
\end{abstract}

Electronic supplementary material The online version of this article (doi:10.1007/s10158-008-0081-7) contains supplementary material, which is available to authorized users.

K. Fabritius-Vilpoux

Fakultät für Naturwissenschaften, Institut für Neurobiologie,

Universität Ulm, Albert-Einstein-Allee 11, 89069 Ulm, Germany

S. Bisch-Knaden $\cdot$ S. Harzsch $(\bowtie)$

Department of Evolutionary Neuroethology,

Max Planck Institute for Chemical Ecology,

Beutenberg Campus, Hans-Knöll-Str. 8, 07745 Jena, Germany

e-mail: sharzsch@ice.mpg.de

\section{S. Harzsch}

Fachbereich Biologie, Zoologisches Institut und Museum,

Cytologie und Evolutionsbiologie,

Ernst-Moritz-Arndt-Universiät Greifswald,

Johann Sebastian Bach Str. 11/12, Greifswald, Germany formation in Crustacea. Recent data on neurogenesis in an amphipod crustacean have provided compelling evidence for the homology of several identified neuroblasts between this amphipod and insects. The present report may serve as a basis to explore the question if during crustacean neurogenesis additional communalities with insects exist.

Keywords Neurogenesis · Neuroblasts · Ventral nerve cord · Neurophylogeny $\cdot$ Evolution . Arthropoda $\cdot$ Tetraconata $\cdot$ Crustacea

\section{Introduction}

The parthenogenetic Marbled Crayfish (Marmorkrebs; Malacostraca, Decapoda, Astacida) is an unidentified crayfish of uncertain geographical origin. Its closest relatives seem to belong to the genus Procambarus (Scholtz et al. 2003). Unpublished molecular analyses of its mitochondrial genome suggest it to be a parthenogentic strain of the North American cambarid Procambarus alleni (Keith Crandall, unpublished data as cited in Vogt et al. 2008). This organism is an outstanding crustacean because it provides the first example for parthenogenesis within the decapod crustaceans (Scholtz et al. 2003; Vogt et al. 2004; Vogt and Tolley 2004; Seitz et al. 2005). Most recently, it has been shown that the Marbled Crayfish reproduces by apomictic parthenogenesis, the most common asexual reproductive mode among invertebrates (Martin et al. 2007; Vogt et al. 2008). By apomictic propagation, the offspring conserve the original genetic information and, thus, are identical clones of the mother (Martin et al. 2007). Due to its high fertility the Marbled Crayfish is an excellent model to explore aspects of crustacean embryology and neurobiology (Seitz et al. 2005; Alwes and Scholtz 2006; 
Vilpoux et al. 2006; Polanska et al. 2007; Sintoni et al. 2007; Rieger and Harzsch 2008).

The segment polarity gene engrailed (en) which encodes a homeobox transcription factor is expressed by cells in the posterior part of a segment during arthropod development. In crustaceans, the expression pattern and role of the Engrailed protein (En) has been intensely studied during segmentation of malacostracan embryos (Patel et al. 1989a, b; Scholtz et al. 1993, 1994; Scholtz 1995; Gerberding and Scholtz 1999; Abzhanov and Kaufman 2000; Browne et al. 2005; reviews: Patel 1994, Scholtz and Dohle 1996, Dohle and Scholtz 1997, Scholtz 1997, Scholtz, 2001). As for crayfish, the pattern of En expression during germ band formation has been thoroughly analyzed in Procambarus clarkii (Patel et al. 1989b) using the monoclonal antibody 4D9 and has also been briefly documented in the Marbled Crayfish (Alwes and Scholtz 2006). In these animals, the cellular material of the post-naupliar germ band is generated by the mitotic action of asymmetrically dividing stem cells, the ectoteloblasts, which give off descendant cell rows in an anterior direction (review Dohle et al. 2004). The progeny of the ectoteloblasts are arranged in precise longitudinal and transverse rows and form a grid-like pattern (Scholtz 1992). The cell rows as generated by the ectoteloblasts cleave twice by mediolateral mitotic waves to generate four regular descendent rows designated a, b, c, d. The entire row a then begins to express En as well as some cells in row b (Patel et al. 1989b; Alwes and Scholtz 2006). The anterior border of row a represents the parasegmental boundary (discussed in detail by Dohle and Scholtz 1988, Dohle et al. 2004). The En stripe then widens by the recruitment of cells from row $b$ that newly express En. Furthermore, at this point a series of differential cleavages begins and each cell divides in a stereotyped manner thus dissolving the grid-like pattern as has been thoroughly documented by Scholtz (1992). Once the differential cleavage begins all progeny of the a row continue to express En (Patel et al. 1989b). Thus, the initial one-cell En stripes widen by a combination of division of En-positive cells and the recruitment of cells which previously did not express En (Patel et al. 1989b; see also Scholtz et al. 1993, 1994). In row b both Enpositive and En-negative progeny is generated. The segmental groove passes posterior to or between the descendents of row $\mathrm{b}$ thus being in discordance with the genealogical border (Dohle and Scholtz 1988; Patel et al. 1989b). From this stage onwards En expressing cells mark the posterior margin of the segments. It should be noted that most of our information on crayfish En expression stems from the analysis of pleon segments (Patel et al. 1989b; Alwes and Scholtz 2006), whereas information on En localization in the more anterior segments is scarce.
In addition to segmentation, several reports exist on the neuronal expression of the En protein in the ventral nerve cord of malacostracan embryos (Scholtz 1995; Harzsch et al. 1998; Duman-Scheel and Patel 1999; Abzhanov and Kaufman 2000; Browne et al. 2005). A detailed comparison of neuronal En expression in Malacostraca with that in Insecta has been undertaken by Duman-Scheel and Patel (1999) who suggested five distinct En-positive cell types to be homologous throughout the two groups. Furthermore, a group of En-positive cells in the embryonic crayfish brain, the secondary headspots, recently was suggested to be homologous to their grasshopper counterparts (Sintoni et al. 2007). Despite these efforts, for the crayfish limited information is available on En expression in neuronal stem cells, the neuroblasts. Neurogenesis in malacostracan crustaceans typically is driven by neuroblasts which repeatedly undergo unequal divisions to produce ganglion mother cells, which later divide again to give birth to ganglion cells (e.g. Dohle 1970, 1972; Scholtz 1990, 1992; Harzsch and Dawirs 1994; Harzsch et al. 1998; Gerberding and Scholtz 2001; Harzsch 2001; Sullivan and MacMillan 2001; Ungerer and Scholtz 2007; reviews Harzsch 2003a, b; Dohle et al. 2004; Whitington 2004). This mode of neurogenesis in principal shares many similarities with that in insects (reviews, e.g. Doe and Technau 1993; Goodman and Doe 1993; Doe and Skeath 1996; Urban and Technau 1997; Campos-Ortega and Hartenstein 1997; Doe et al. 1998; Skeath 1999; Matsuzaki 2000; Skeath and Thor 2003; Technau et al. 2006). While most studies on insect neurogenesis have been carried out in grasshoppers and the fruit fly, studies on other insects such as the moth Manduca sexta (Booker and Truman 1987; Booker et al. 1996) and the beetle Tenebrio molitor (Breidbach and Urbach 1996; Urbach et al. 2003) indicate the universal presence of neuroblasts in this taxon (review Urbach and Technau 2003). Neuroblasts were also studied in the silverfish, a primarily wingless insect and the array of neuroblasts in this species is evolutionarily conserved in the winged insects (Truman and Ball 1998). In several representatives of this group of organisms all neuroblasts in the thoracic ganglia are individually identified concerning their position and the lineage which they generate and are well characterized on the molecular level (e.g. Doe 1992; Doe and Technau 1993; Broadus et al. 1995; Bossing et al. 1996; Schmidt et al. 1997; see also the hyper neuroblast map at http://www.neuro.uoregon. edu/doelab/nbintro.html). In grasshoppers and the fruit fly, neuroblasts of row six and seven as well as one neuroblast of row one express the gene engrailed (Doe 1992). The goals of our study were to chart the spatial and temporal patterns of En positive cells in the crayfish neuroectoderm and to find out if En positive stem cells (neuroblasts) are present. To this end, we performed an immunohistochemical single-cell analysis of En 
expression in whole mount embryos of the Marbled Crayfish. Our analysis connects to that of Patel et al. (1989b) and Alwes and Scholtz (2006) in that we charted En positive cells in the neuroectoderm in later embryonic stages when segmentation is already completed.

\section{Materials and methods}

Animals

Marbled Crayfish (Malacostraca, Decapoda, Astacida) were reared in the laboratory at $20^{\circ} \mathrm{C}$ water temperature and a 10:14 h light-dark regime as described by Seitz et al. (2005). Embryos were staged according to normalized developmental schemes (E0\% equals extrusion of eggs, E100\% equals hatching) as established by Seitz et al. (2005).

Immunohistochemistry and histochemistry

Dissected embryos were fixed for 30 min in PEM-FA fixative $(0.1 \mathrm{M}$ Pipes buffer $\mathrm{pH} 6.95,2 \mathrm{mM}$ EGTA, $1 \mathrm{mM}$ $\mathrm{MgSO}_{4}, 3.7 \%$ formaldehyde) at room temperature. Specimens were then washed in several changes of PBS $(0.1 \mathrm{M}$ phosphate-buffered saline $\mathrm{pH}$ 7.4) for $1.5 \mathrm{~h}$ and afterwards preincubated for $30 \mathrm{~min}$ in PBS-TX (PBS, 0.3\% Triton X100). The monoclonal anti-Engrailed antibody 4D9 (Patel et al. $1989 \mathrm{a}, \mathrm{b})$ was supplied as a partially purified $\mathrm{IgG}$ $(166 \mu \mathrm{g} / \mathrm{ml})$ by the Developmental Studies Hybridoma Bank (University of Iowa) and diluted 1:25 in PBS-TX for application. The embryos were incubated in the primary antibody overnight at $4{ }^{\circ} \mathrm{C}$. In control experiments, the omissions of the primary antibody abolished all neuronal labelling. After washing in several changes of buffer for $1.5 \mathrm{~h}$ in PBS, specimens were incubated in a peroxidaseconjugated anti-mouse antibody (Sigma) for $2 \mathrm{~h}$ at room temperature (1:1,000 in PBS) and then washed again in several changes of PBS overnight at $4^{\circ} \mathrm{C}$. The label was developed in $0.013 \%$ diaminobenzidine with peroxide substrate and metal enhancer (from Amersham BrdU kit RPN 20). Subsequently, specimens were washed for $1 \mathrm{~h}$ in PBS, dehydrated in a graded series of ethanol, transferred to methyl salicylate and finally mounted in Entellan diluted with methyl salicylate. Alternatively, the samples were incubated in a secondary anti-mouse antibody conjugated to Alexa Fluor 488 (1:1,000 in PBS; Molecular Probes) for $2 \mathrm{~h}$ at room temperature, washed in PBS and mounted in Gel Mount (Sigma). More than 300 embryos were processed successfully for Engrailed immunohistochemistry.

The embryonic nervous system was labelled with phallotoxins conjugated to a fluorescent dye (Vilpoux et al. 2006). Briefly, dissected embryos were fixed in $4 \%$ paraformaldehyde in $0.1 \mathrm{M}$ phosphate buffer ( $\mathrm{PB}, \mathrm{pH} 7.4)$ for $4 \mathrm{~h}$ at room temperature. Specimens were then washed in several changes of phosphate-buffered saline (PBS, $\mathrm{pH}$ 7.4) for $1.5 \mathrm{~h}$ or overnight at $4^{\circ} \mathrm{C}$ and afterwards preincubated for $30 \mathrm{~min}$ in PBS with $0.3 \%$ Triton X-100 (PBSTX) at room temperature. Phallotoxins conjugated to Alexa Fluor 488 (Molecular Probes; concentration 200 units/ml) were diluted 1:50 in PBS-TX. The whole mounts were incubated in this solution for $1 \mathrm{~h}$ at room temperature, then washed for at least $1.5 \mathrm{~h}$ in several changes of PBS and finally mounted in Gel Mount (Sigma).

Proliferation of cells was monitored by in vivo labelling with bromodeoxyuridine (BrdU; Dolbeare 1996). Embryos were exposed to BrdU (Amersham Int., Little Chalfont, Buckinghamshire, UK; Cell Proliferation Kit RPN 20) diluted in a crayfish ringer solution to a concentration of $0.2 \mathrm{mg} / \mathrm{ml}$ for $4 \mathrm{~h}$ at $18^{\circ} \mathrm{C}$. This $4 \mathrm{~h}$ time span has been found to provide a strong labelling of cycling cells while the number of labelled cells is still low enough to be analyzed efficiently (Harzsch and Dawirs 1994). Whole mounts of the embryos were processed immunohistochemically (Harzsch and Dawirs 1994). Briefly, specimens were incubated for $2.5 \mathrm{~h}$ in a primary anti-BrdU mouse antibody (1:100, Amersham, Cell Proliferation Kit RPN 20) and afterwards for $1 \mathrm{~h}$ in a peroxidase-coupled secondary goat anti-mouse antibody (1:70). The signal was developed with diaminobenzidine.

Digital images were obtained with a Zeiss Axioskop fitted with a CCD-1300B digital camera (Vosskühler $\mathrm{GmbH}$ ) and processed with the Lucia Measurement 5.0 software package (Laboratory Imaging Ltd.). The fluorescent samples were scanned with a Leica confocal laserscanning microscope. Images are based on stacks of 15-20 optical sections (single images are averages of four laser sweeps) of a $z$-series taken at intervals of $1 \mu \mathrm{m}$. The colour-coded red-green 3-D images were generated from these stacks using the Leica software.

\section{Specificity of the monoclonal antibody 4D9}

The generation of the monoclonal antibody 4D9 has been described in detail by Patel et al. (1989a). The immunogen used were the C-terminal two-thirds of the Drosophila invected protein as generated in $E$. coli with the T7 polymerase expression system. BALB/c mice were immunized with the proteins by intraperitonial injections. Their spleen cells were fused with NS-1 myeloma cells (Patel et al. 1989a). Antibody 4D9 is an IgG1 that recognizes the engrailed and invected gene products of Drosophila. The epitope has been localized to residues 38-58 of the homeodomain, and this epitope is conserved between invected and engrailed proteins. Immunolocalization experiments with this antibody in Drosophila, grasshoppers, 
crayfish and other crustaceans have provided evidence for consistent staining patterns during embryonic segmentation suggesting an evolutionary conservation of the epitope that 4D9 recognizes across the Euarthropoda (Patel et al. 1989a, b; Scholtz et al. 1993, 1994; Browne et al. 2005; Alwes and Scholtz 2006). Abzhanov and Kaufman (2000) have cloned partial cDNAs of engrailed from crayfish and for this organism have reported the presence of two engrailed paralogous, enl and en2, similar to the situation in insects. By comparing in situ hybridization expression data with the 4D9 immunolocalization patterns, Abzhanov and Kaufman (2000) concluded that monoclonal antibody 4D9 in crustaceans recognizes both engrailed paralogous. Nevertheless, since the Marbled crayfish engrailed genes have not been characterized yet, we cannot be sure which protein exactly 4D9 binds to in this species. Therefore, we will refer to labelled cells as "Engrailed-like immunoreactive" cells throughout the paper.

Mapping and size measurements of the labelled cells

The Engrailed-like immunoreactive (En-li+) cells in the ventral nerve cord were mapped by viewing the ventral side of the embryos with a $100 \times$ magnification objective (Zeiss Axioskop) and drawing specimens with a camera lucida device at an additional $11 \times$ magnification. Only those cells were charted that considering their position were clearly localized medially within the neuroectoderm whereas more lateral cells that were part of the developing limb buds were omitted. Cells with an unclear position were excluded from the analysis so that our maps and cell counts slightly underestimate the numbers of neuronal Enli+ cells. The size of labelled cells was measured by tracing the cell outline in images obtained with the digital camera on the computer screen. Calculations of the cell area were performed with the measurement tool of the Lucia Measurement 5.0 software package (Laboratory Imaging Ltd.). Only those cells were included that were strongly labelled above the background signal. This way, 2,052 cells in twelve specimens were measured. One representative drawing of each embryonic stage was chosen, digitized with a scanner and the cell arrangement then reconstructed with the CorelDRAW Graphics Suite 12 software. The tissue of older embryonic stages becomes thicker. Therefore, we were unable to map and measure En-li+ cells in embryos older than E46\%. The size distribution of labelled cells in twelve embryos was plotted in normalized bar diagrams with a class width of $5 \mu \mathrm{m}^{2}$ (e.g. 40-45 $\mu \mathrm{m}^{2}$, class median $42.5 \mu \mathrm{m}^{2}$ ). The size distribution displayed several frequency minima that we analyzed in more detail. We selected those putative minimum classes that on both sides were flanked by classes with absolute values at least two counts higher than the class of the putative minimum. The number of the minimum classes thus determined were plotted in a separate bar diagram.

\section{Results}

Quantification of Engrailed-like immunoreactive $($ En-li+) in the neuroectoderm

We began our quantification of En-li+ cells in the ventral neuroectoderm at $38 \%$ of embryonic development (E38\%) and focussed on four segments: the neuromeres of the mandible, maxilla one, maxilla two and thoracomere one. At this stage, these four segments are fully formed, limb buds begin to emerge, and the initial single stripes of En$\mathrm{li}+$ cells begin to widen considerably. Pooled counts of En$\mathrm{li}+$ cells for these four segments revealed that between E38 and $\mathrm{E} 46 \%$ the expression of Engrailed-like proteins is dynamic (Fig.1). The numbers of neuroectodermal En-li+ cells from E38\% onwards first increases strongly to reach a plateau around $\mathrm{E} 42 \%$ and decreases again towards E46\%. Hence, within only $3 \%$ of embryonic development (from E38\% with an average of 85 En-li+ cells, $n=3$ embryos, to E40\% with an average of 260 En-li+ cells, $n=3$ embryos), we observed a threefold increase of En-li+ cells.

In individual specimens we observed a pronounced anterior-posterior gradient in the numbers of En-li+ cells within the four segments that we analyzed (Fig. 2). In early embryos at E38\%, around $25 \mathrm{En}-\mathrm{li}+$ cells are present in the neuromeres of the mandible, maxilla one and maxilla two. Yet, at this stage, an average $(n=3)$ of only 11 labelled cells have emerged in the neuroectoderm of thoracomere one. In E39\% embryos, the mandible and the maxilla one

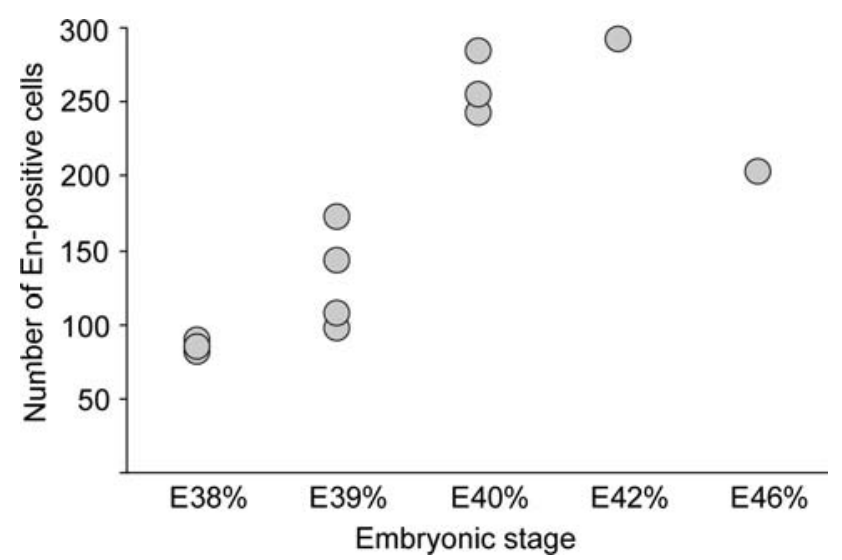

Fig. 1 Quantification of Engrailed-like immunoreactive (En-li+) cells in the developing ventral nerve cord of Marbled Crayfish embryos $(n=12)$ from E38 to E46\%. The number of labelled cells was added up for four neuromeres of the ventral nerve cord (mandible neuromere to thoracomere one; for morphological terminology compare Harzsch 2003a; Vilpoux et al. 2006) 
Fig. 2 Mapping of En-li+ cells in the embryonic

neuroectoderm. Ventral views of an individual embryo at E38\% (a, b) and an early E39\% embryo (c, $\mathbf{d}$; the contours of the caudal papilla and limb anlagen are outlined by stippled lines). In $\mathbf{a}$ and $\mathbf{c}$ the cells are coloured according to their ventral to dorsal position (depth coding; see legend provided in Fig. 4d). In $\mathbf{b}$ and $\mathbf{d}$ the cells are coloured according to their size (size coding; see legend provided in Fig. 4d). Letters label individually identified cells (compare Fig. 8). The cell size measurements for the specimens shown are given in a and $\mathbf{b}$ correspond to embryo 1 , and $\mathbf{c}$ and $\mathbf{d}$ to embryo 6. Abbreviations: $C P$ caudal papilla; $M D$ mandible segment; M1, M2 maxilla one and two segments; $T 1$ thoracomere one. Scale bars $25 \mu \mathrm{m}$
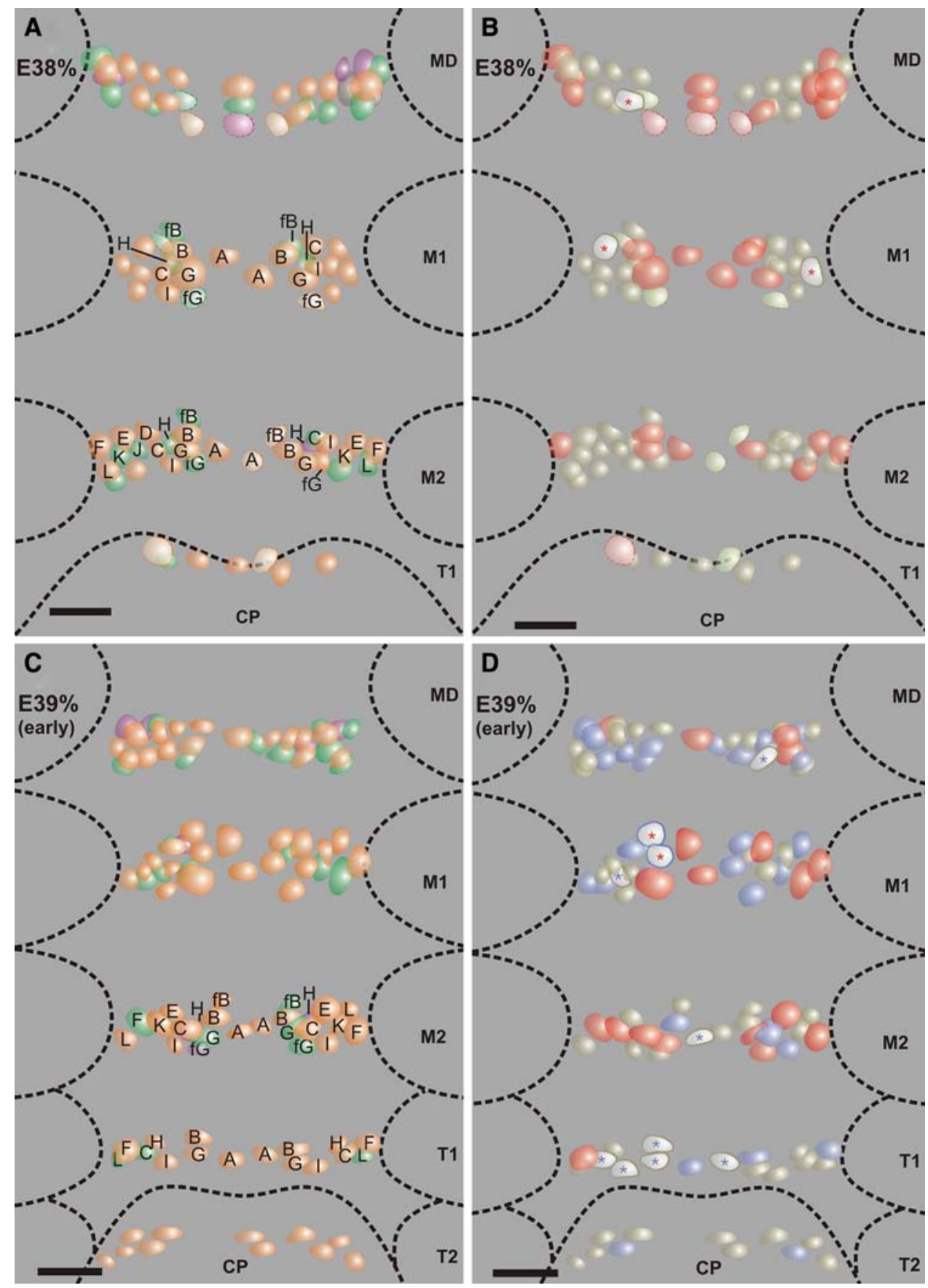

neuromeres contain around 36 En-li+ cells $(n=3)$, while in the maxilla two neuromere we charted an average $(n=3)$ of 27 and in the thoracomere one an average of 18 En-li+ cells. Thus, in this phase of embryogenesis, the number of En-li+ cells seems to increase slightly faster in the more anterior neuromeres. Around $42 \%$ of embryonic development, each of the neuromeres that we analyzed reaches a maximum of En-li+ cells (Figs. 3c, d, 4a, b). The maximum count for the mandible neuromere of one individual embryo was $62 \mathrm{En}-\mathrm{li}+$ cells. The more posterior neuromeres reach an even higher number of En-li+ cells with numbers increasing from anterior to posterior: in the maxilla one neuromere of this specimen we counted 74 cells, in the maxilla two neuromere 78 cells, and in thoracomere one 80 cells. At E46\% the number of En-li+ cells has decreased to 34 in the mandible neuromere of one individual specimen. In this specimen, $54 \mathrm{En}-\mathrm{li}+$ cells are present in the maxilla two neuromere and 46 in the thoracomere one (Fig. 4b). As will be shown later, the expression of Engrailed-like proteins vanishes rapidly from the neuromeres of the mandible and maxilla one from $\mathrm{E} 46 \%$ onwards. By E65\% has reached a level that cannot 
Fig. 3 Mapping of the En-li+ cells in the ventral nerve cord. Ventral views of individual embryos at late E39\% (a, b) and at $\mathrm{E} 42 \%$ (c, d). The depth coding in $\mathbf{a}$ and $\mathbf{c}$ and the size coding in $\mathbf{b}$ and $\mathbf{d}$ is the same as in Fig. 2. Letters label individually identified cells (compare Fig. 8). The En-li+ cluster of median neuroblast progeny is indicated (MP). The cell size measurements for the specimens shown are given in Figs. S1, S2: a and b correspond to embryo 4 , and $\mathbf{c}$ and $\mathbf{d}$ to embryo 11. Abbreviations: $C P$ caudal papilla; $M D$ mandible segment; $M 1, M 2$ maxilla one and two segments; $M P$ median neuroblast progeny; $T 1$

thoracomere one. Scale bars $25 \mu \mathrm{m}$

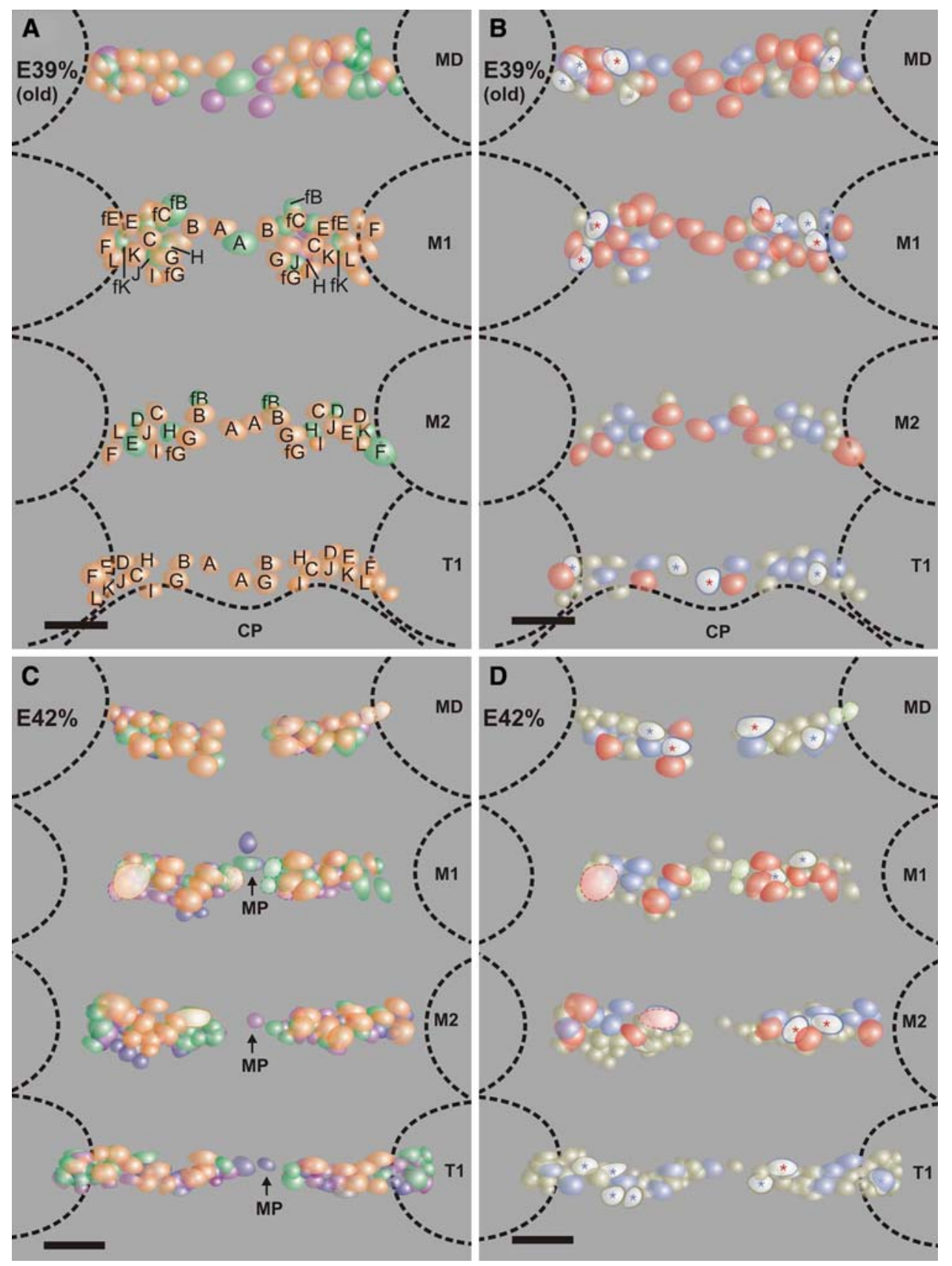

be detected immunohistochemically any more in these two neuromeres. Nevertheless, during late embryogenesis strong neuronal and glial expression is still present in the more posterior neuromeres from the maxilla two downwards the length of the ventral nerve cord (see below).

\section{Size distribution of En-li+ cells}

At a first glance, the size of the En-li+cells appeared to be continuous. However, in order to determine if certain size classes of cell types may be present, we decide to measure the cells. Cell area measurements obtained between E38 and E46\% showed that the size distribution of En-li+ cells in the neuroectoderm is highly dynamic as development proceeds (Figs. S1, S2). At E38\%, the size frequency of the 90 cells that we measured in the four neuromeres of embryo No. 1 appears to have a trimodal distribution with two distinct frequency minima (asterisks in Fig.2, embryo 1) suggesting the presence of three distinct populations of cells. Because at close inspection, frequency minima were present in most of the twelve embryos that we analyzed, we systematically charted the occurrence of the minima (Fig. S3). Twenty-one minima were determined from the size measurements of 12 embryos (asterisks in Fig. S2, S3). The 
Fig. 4 Mapping of the En-li+ cells in the ventral nerve cord. Ventral views of embryos at $\mathrm{E} 46 \%(\mathbf{a}, \mathbf{b})$ and at $\mathrm{E} 52 \%$ (c). In $\mathbf{a}$ and $\mathbf{c}$ the cells are coloured according to their ventral to dorsal position (depth coding) and in $\mathbf{b}$ according to their size (size coding). Letters label individually identified cells (IC and EC neurons, median neuroblast progeny; compare Fig. 8). The cell size measurements for the specimen shown in $\mathbf{a}$ and $\mathbf{b}$ are given in Fig. S2 (embryo 12). d legend of the colour coding of the cell drawings shown in Figs. S2-S4. Abbreviations: EC EC neurons; $I C$ IC neurons; $M D$ mandible segment; $M 1, M 2$ maxilla one and two segments; $M P$ median neuroblast progeny; $T 1$ thoracomere one. Scale bars $25 \mu \mathrm{m}$
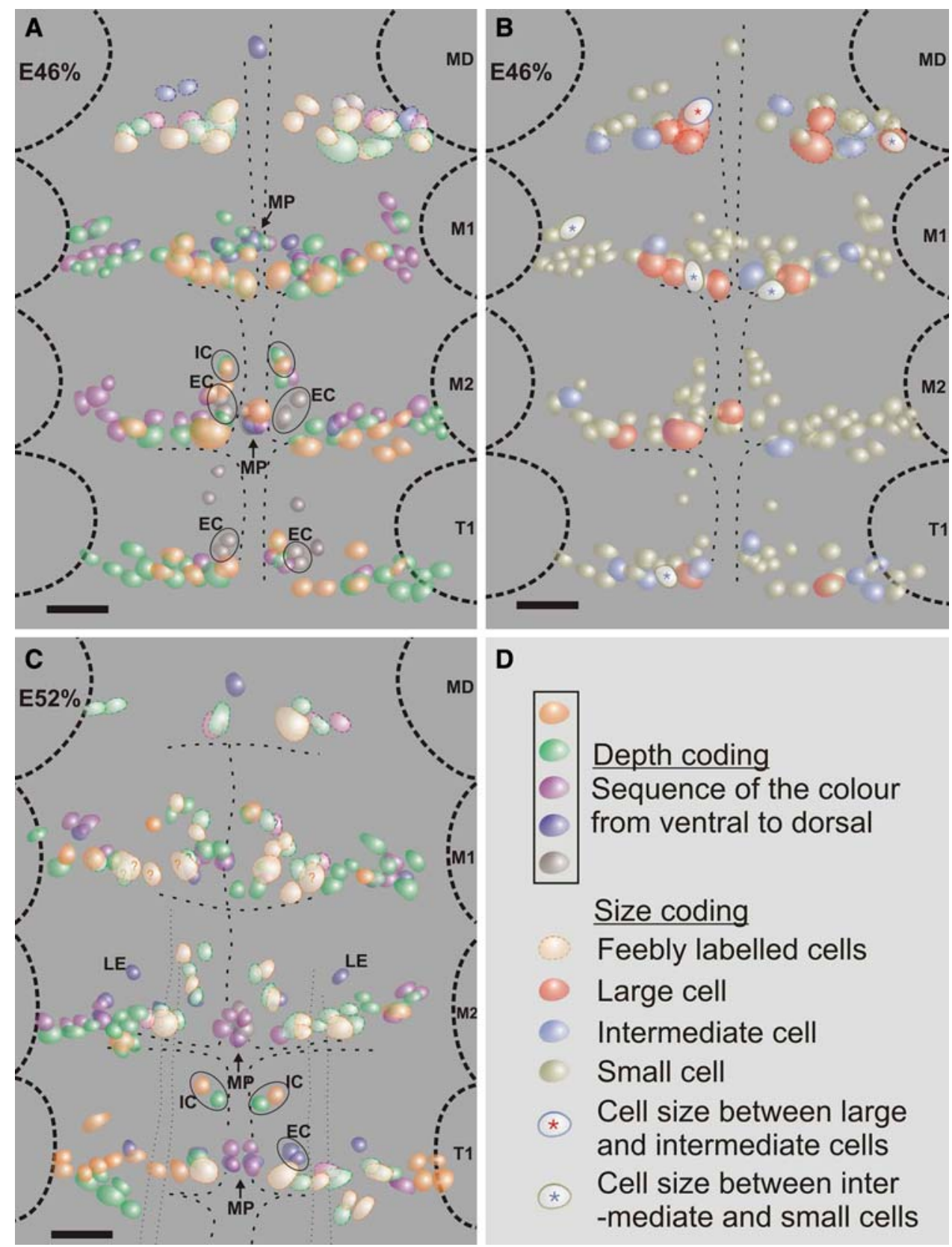

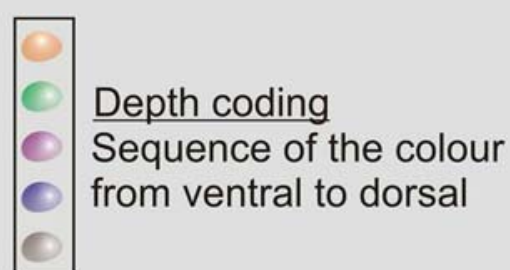

\section{Size coding}

Feebly labelled cells

- Large cell

Intermediate cell

Small cell and intermediate cells

Cell size between inter -mediate and small cells
Cell size between large minima are concentrated in two size classes, the size class from 60 to $65 \mu \mathrm{m}^{2}$ ( 6 minima) and the size class from 70 to $75 \mu^{2}$ (5 minima), whereas in some other classes, only 1 or 2 minima occur. This raises the possibility, that concerning cell size, different populations of En-li+ cells are present in the ventral neuroectoderm, namely a class of "large" cells above ca. $75 \mu^{2}$, a population of "small" cells below $60 \mu^{2}$ and possibly a third population of "intermediate" cells between 60 and $75 \mu \mathrm{m}^{2}$.

For all embryos that we analyzed, the overall number of cells in the "large" class is lower than that in the two other size classes. Furthermore, as development proceeds, it seems that the cell size distribution more and more shifts from the "large" and "intermediate" classes towards the "small" size class. In the younger embryos No 1-7 (E38-E39\%; Fig. 2), $22 \%( \pm 10 \%)$ of the En-li+ cells fall into the "large" size class whereas an average of $54 \%( \pm 14 \%)$ are "small" cells. In embryos No 8-12 (E40-E46\%), only $12 \%( \pm 2 \%)$ are "large" cells whereas the vast majority of En-li+ cells falls into the class of "small" cells and on average make up $73 \%$ $( \pm 2 \%)$ of the En-li+ cell population (Figs. S1, S2).

\section{Mapping of the En-li+ cells from E38 to E40\%}

Figures 2, 3 and 4 show maps of En-li+ cells in the neuroectoderm and, later, in the developing ventral nerve cord 
as drawn from individual embryos. We focussed our analysis on the neuromeres of the mandible down to thoracomere one. All of the embryos charted have also been processed for cell counts and size measurements and this correspondence is indicated in the legends. In these plates, the sketches on the left size are colour coded according to the ventral to dorsal arrangement of the cells. This represents a system of relative (and not absolute) depth coding displaying the arrangement of individual cells relative to their ventral and dorsal neighbours (see Fig. 4D for a legend). In the sketches on the right side, the same specimens are drawn again but with a size coding of the En-li+ cells. Cells in size classes larger than that of the upper frequency minimum $\left(70-75 \mu \mathrm{m}^{2}\right.$; see Fig. S3) were qualified as "large" cells and coded in red. Cells that fell into the class of the upper minimum were drawn in white and labelled with a red asterisks to indicate that their size was in between the "large" and "intermediate" type of cells. The same system was applied for the "intermediate" (blue) and "small" (green) cell populations (see legend in Fig. 4d). Hence, only those cells were colour coded that fell well into the populations of "large", "intermediate", or "small" cells.

The patterns of labelled cells in all embryos that we screened displayed recognizable left-right symmetry. Furthermore, between the segments of maxilla one, maxilla two and thorax one, whilst taking into account the anteriorposterior gradient of maturation, we were able to clearly recognize a segmentally iterated pattern of cells so that we attempted to identify and label the cells individually. We were successful with this approach for embryos between E38\% and about E40\% (Figs. 2, 3, 5, 6, 7) although there is a considerable variation in the arrangement of cells between different specimens and sometimes also between the left and right sides of one neuromere in a given embryo. The individually identified En-li+ cells were arbitrarily labelled with Arabic letters assuming they were arranged in two rows stretching from the midline to the side. We failed to analyse the pattern of En-li+ cells in subsequent developmental stages due to the strongly increasing number of cells. Furthermore, we excluded the mandible neuromere from our analysis at the single-cell level because we found the pattern in this neuromere to be different from that in the more posterior segments.

At E38\%, the complete set of ectoteloblasts which are arranged in a circle surrounding the caudal papilla expresses Engrailed-like immunoreactivity (Fig.5g, h), an observation that had not been reported in the studies neither of Patel et al. (1989b) nor of Alwes and Scholtz (2006) who apparently examined older embryos than we did. Nevertheless, in our specimens, serially iterated ectodermal cell rows in front of the ectoteloblasts also show Engrailed-like immunoreactivity (Fig. 5g, h) which is in good accordance
Fig. 5 Whole mounts of dissected E38\% embryos, ventral views. a En immunoreactivity showing segmentally iterated stripes of labelled cells in the trunk segments. b Phalloidin histochemistry to label actin reveals the axonal architecture of the embryonic brain at this embryonic stage (compare Vilpoux et al. 2006). c Labelling with the in vivo mitosis marker bromodeoxyuridine reveals a high level of mitotic activity throughout the entire embryo including the brain, limb anlagen and the developing ventral nerve cord. d-f Details of the En immunoreactivity from the embryo shown in (a midline is indicated by stippled line; letters label individually identified cells, compare Fig. 8. d ventral aspect of the mandible $(M D)$ and the maxilla one (M1) neuromeres, e the maxilla neuromere two (M2). f En expression in thoracomere one. $\mathbf{g}$, $\mathbf{h}$ High magnification images of the growth zone in the caudal papilla of different embryos showing the En-li+ ectoteloblasts $(E T)$ and the En-li+ cells of row 'ab' corresponding to the second thoracomere (compare Alwes and Scholtz 2006). The circle in $\mathbf{h}$ identifies the daughters from the equal division of the midline cell $\mathrm{a}_{0}$ (compare Gerberding and Scholtz 1999). Abbreviations: A1, A2 Antenna one and two; $C P$ caudal papilla; $E T$ ectoteloblast; $M D$ mandible segment; $M 1, M 2$ maxilla one and two segments; $O A$ optic anlagen. Scale bars a-c $50 \mu \mathrm{m}$, d-f $25 \mu \mathrm{m}, \mathbf{g}-\mathbf{h} 10 \mu \mathrm{m}$

with the observations by Patel et al. (1989b) and Alwes and Scholtz (2006). In thoracomere one, a single row of En-li+ cells is present at E38\% (Figs. 2a, d, 5f, 6d). More elaborate patters of En-li+ cells are present in the more anterior segments (Fig. 5a; see below). Phalloidin histochemistry to label actin reveals the axonal architecture of the embryonic brain at this stage (Fig. 5b; compare Vilpoux et al. 2006). A primordial scaffold of the brain is present in the protocerebral (optic anlagen), deutocerebral (antenna 1), and tritocerebral (antenna 2) neuromeres as well as the mandible segment (representing the "naupliar brain"; Vilpoux et al. 2006). However, there is no evidence for axonal tracts stretching further caudally from the mandible segment at E38\% (Fig. 5b). Labelling with the in vivo mitosis marker bromodeoxyuridine reveals a high level of mitotic activity throughout the entire embryo including the brain, limb anlagen and the developing ventral nerve cord (Fig. 5c).

At E38\%, most of the En-li+ cells are arranged in just a single layer (considering the dorso-ventral extension; Fig 2a). Twelve cells, labelled A to $\mathrm{L}$ were identified individually on each side of E38\% embryos as shown in the schematic representation in Fig. 8. This scheme is based on the analysis of 15 specimens per stage. Figures $2 a, 5 d$, e, and $6 \mathrm{a}-\mathrm{c}$ signify that the position of these cells may vary considerably between the left and right side of one specimen or between different specimens of the same stage. Hence, not every single cell is visible in the drawings (which represent individual embryos) or photos. As we had already concluded from the cell counts, there is an anterior to posterior developmental gradient with the posterior segments being less developed than the anterior ones. Hence, by analysing the various segments in every single embryo several steps in the maturation of the En-li+ cell pattern are captured. In should be noted, however, that the 

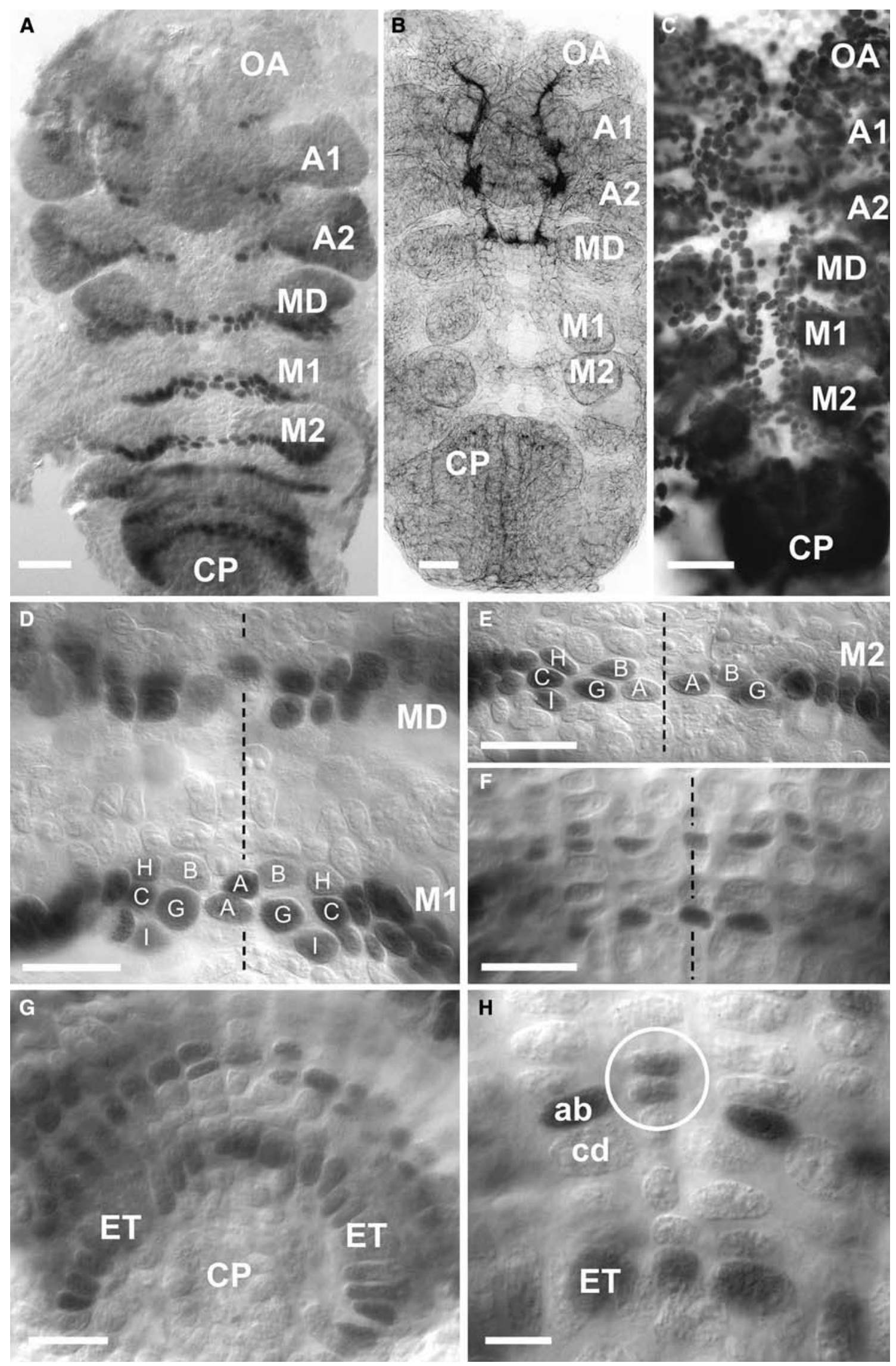

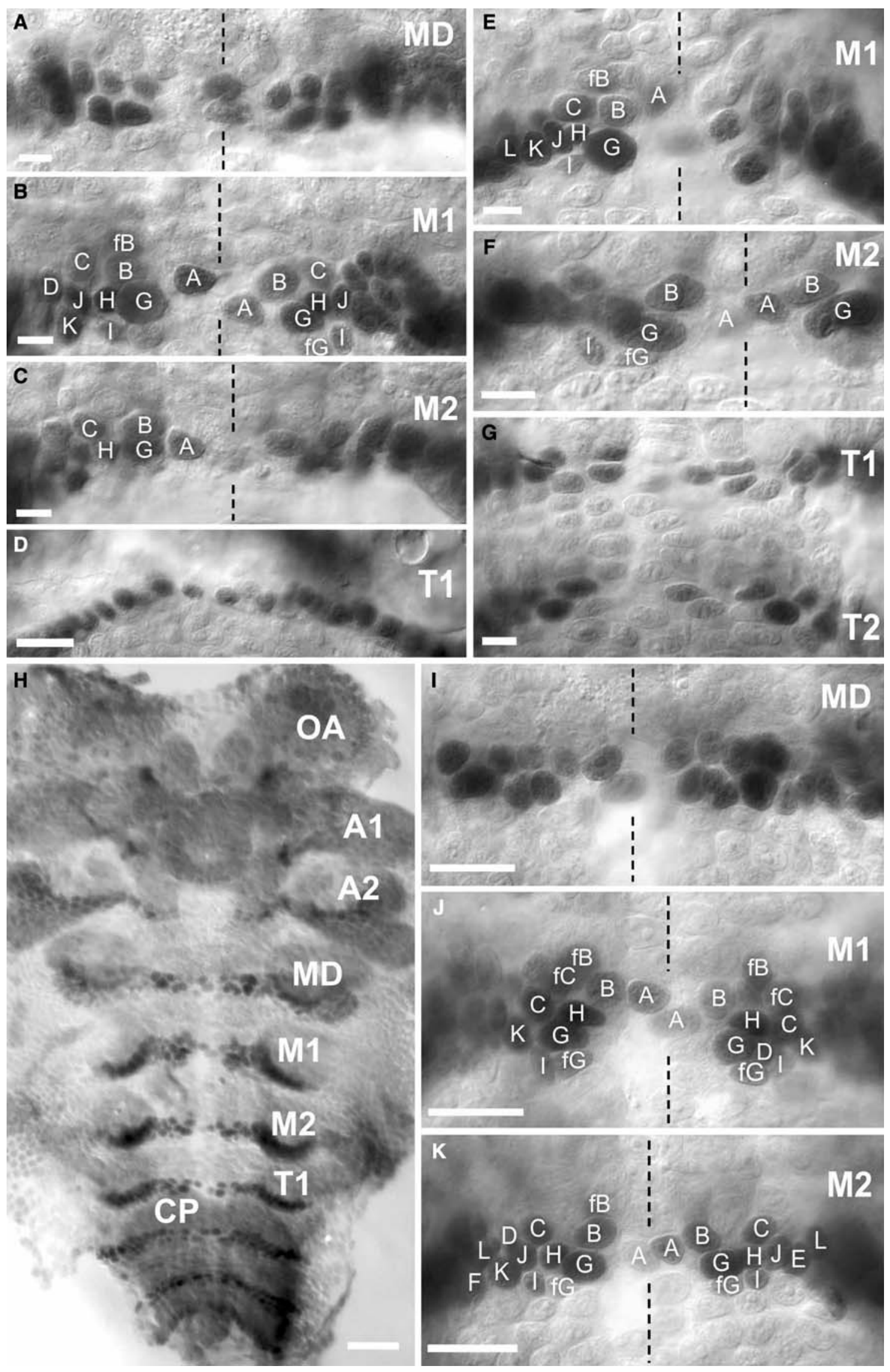
4 Fig. 6 En-li+ immunoreactivity in dissected embryos from E38 to E39\%. a-d the neuromeres from the mandible to thoracomere one at E38\%. Note the anterior-posterior gradient in numbers of labelled cells. d shows the first row of En-li+ ectoderm cells whereas in the more anterior segments neuronal progenitors have emerged. $\mathbf{e}-\mathbf{g}$ An early E39\% embryo. $g$ The newly generated thoracomere two can be distinguished. h-k A late E39\% embryo. h Overview of a whole embryo, flanked by detail images of its mandible (I), maxilla one (j) and maxilla two (k) neuromeres. Abbreviations: A1, A2 Antenna one and two; $C P$ caudal papilla; $M D$ mandible segment; $M 1, M 2$ maxilla one and two segments; $O A$ optic anlagen; $T 1$ thoracomere one; letters label individually identified cells (compare Fig. S4). Scale bars a-c, e-g $10 \mu \mathrm{m}, \mathbf{d}, \mathbf{i}-\mathbf{k} 25 \mu \mathrm{m}, \mathbf{h} 50 \mu \mathrm{m}$

emergence of new En-li+ cells is a continuous process so that our artificial subdivision into five stages (Fig. 8) is only for the sake of convenience. The pattern No 1 in Fig. 8 corresponds roughly to the pattern seen in the maxilla two neuromere of E38\% embryos (Fig. 5e, c) or thoracomere one in early E39\% (Fig. 2c, d) and or thoracomeres one and two in late E39\% embryos (Fig. 7a, b). It consists of two transverse rows of En-li+ cells (per hemineuromere) that extend laterally from the midline. The cell $\mathrm{A}$ is located closest to the midline and most likely derives from the equal division of the midline cell $\mathrm{a}_{0}$ (circle in Fig. 5h; compare Gerberding and Scholtz 1999). In the beginning, the two sister cells that derive from cell $\mathrm{a}_{0}$ are closely associated, but subsequently they separate from each other in a lateral direction (Fig. 2a, 5d, e, 6b) to reach a position as is depicted in pattern No 1 (Fig. 8). In this pattern, only the cell $\mathrm{F}$ has reached a size that corresponds to the category defined as "large" cells and hence is labelled red in Fig. 8.

Patterns No 2 and 3 of our scheme (Fig. 8) are characterized by the enlargement of several cells from the initial two rows to reach the "large" size category. These patterns are present in the maxilla one neuromeres of E38\% embryos, the maxilla one and two neuromeres of early E39\% embryos (Figs. 2, 6e, f), and the maxilla two neuromere of late E39\% embryos (Figs. 6k, 7c). In pattern No 2, cells $\mathrm{A}, \mathrm{B}$, and $\mathrm{G}$, and in pattern No 3, cells $\mathrm{C}$ and $\mathrm{E}$ have enlarged such as to reach the "large" size category. Furthermore, in pattern No 3, two cells newly express Engrailed-like immunoreactivity: fB (friend of B), and $\mathrm{fG}$ (friend of G; see, e.g. Figs. 6b, e, f, j, k). We do not know if these two cells emerged by the division of En-li+ cells or the recruitment of existing cells which previously did not express En. Our experiments with the in vivo mitosis marker bromodeoxyuridine in fact demonstrated a persistently high level of mitotic activity throughout the neuroectoderm between E38\% (Fig. 5c) and E40\% (Fig. 7f). Pattern 4 is also characterized by the enlargement of several "small" cells to reach the "intermediate" size category (Fig. 8).

Pattern No 5 (Fig. 8) is the last one we managed to chart at the level of individually identified cells because during subsequent development the pattern becomes too complex. Pattern No 5 is present in the maxilla one neuromere at late E39\% (Fig. 3a, b), and the maxilla one and two neuromeres at $\mathrm{E} 40 \%$ (Fig. $7 \mathrm{~g}$ ). Compared to pattern No 4, five more cells ( $\mathrm{fB}, \mathrm{fC}, \mathrm{fG}, \mathrm{K}, \mathrm{L}$ ) have enlarged to meet the "large" cell class so that now 11 "large" cells are present per hemineuromere. Furthermore, cells $\mathrm{E}$ and $\mathrm{K}$ are now associated with the new cells $\mathrm{fE}$ and $\mathrm{fK}$, respectively. In addition, several other unidentified En-li+ cells in the "small" size category are present and are located dorsally to the "large" cells, deeper within the embryo (Fig. 2a, b; maxilla one neuromere). The "large" cells generally remain ventrally in the most superficial layer of the neuroectoderm. Labelling with bromodeoxyuridine reveals a high level of mitotic activity throughout the entire neuroectoderm of an E42\% embryo (Fig. 7f) which raises the possibility that at least some of the "large" En-li+ cells may by asymmetrically dividing stem cells that give off smaller progeny in a dorsal direction. This view would be consistent with the rapid increase in numbers of En-li+ cells between E39 and E40\% (Fig. 1). Histochemical localization of actin shows that at E42\%, in addition to the "naupliar brain", the axonal scaffold of the typical ropeladder nervous system is emerging in the segments of the maxilla one and two (Fig. 7e). This suggests that in these neuromeres neurons should be present that have extended axons to form this scaffold (see also Vilpoux et al. 2006). In this part of the Marbled Crayfish nervous system the period between E38\% and ca. E42\% is a phase of intense neurogenic activity. Further caudally in the pleon, new ectodermal stripes are continuously being generated showing that the germ band extension is still in progress at E40\% (Fig. 7h). By E52\% the last ectodermal row of Enli+ cells has been formed and ectoteloblast are no longer visible (Fig. 11a-c).

\section{Mapping of the En-li+ cells from E42 to E65\%}

With almost 300 cells the number of En-li+ cells reaches a climax around $\mathrm{E} 42 \%$ in the four neuromeres that we analyzed (Fig. 1). This means that roughly $40 \mathrm{En}-\mathrm{li}+$ cells are now present per hemineuromere (Fig. 3c, d). The vast majority of these cells belong to the "small" cell population (Fig. S2) and are located dorsally to the remaining "intermediate" and "large" cells. In the neuromeres of the mandible through to maxilla two typically only three to six "large" cells per hemineuromere are En-li+ at E42\% as compared to eleven at $\mathrm{E} 40 \%$. We did not seriously attempt to relate the remaining cells to the full pattern No 5 of identified cells (Fig. 8). However, we suspect that the cells $\mathrm{B}, \mathrm{fB}, \mathrm{G}$, and $\mathrm{fG}$ may be among those remaining large cells at $\mathrm{E} 42 \%$ (Fig. 3C; neuromeres of maxilla one and two) whereas En expression seems to be lost in cells A. This 


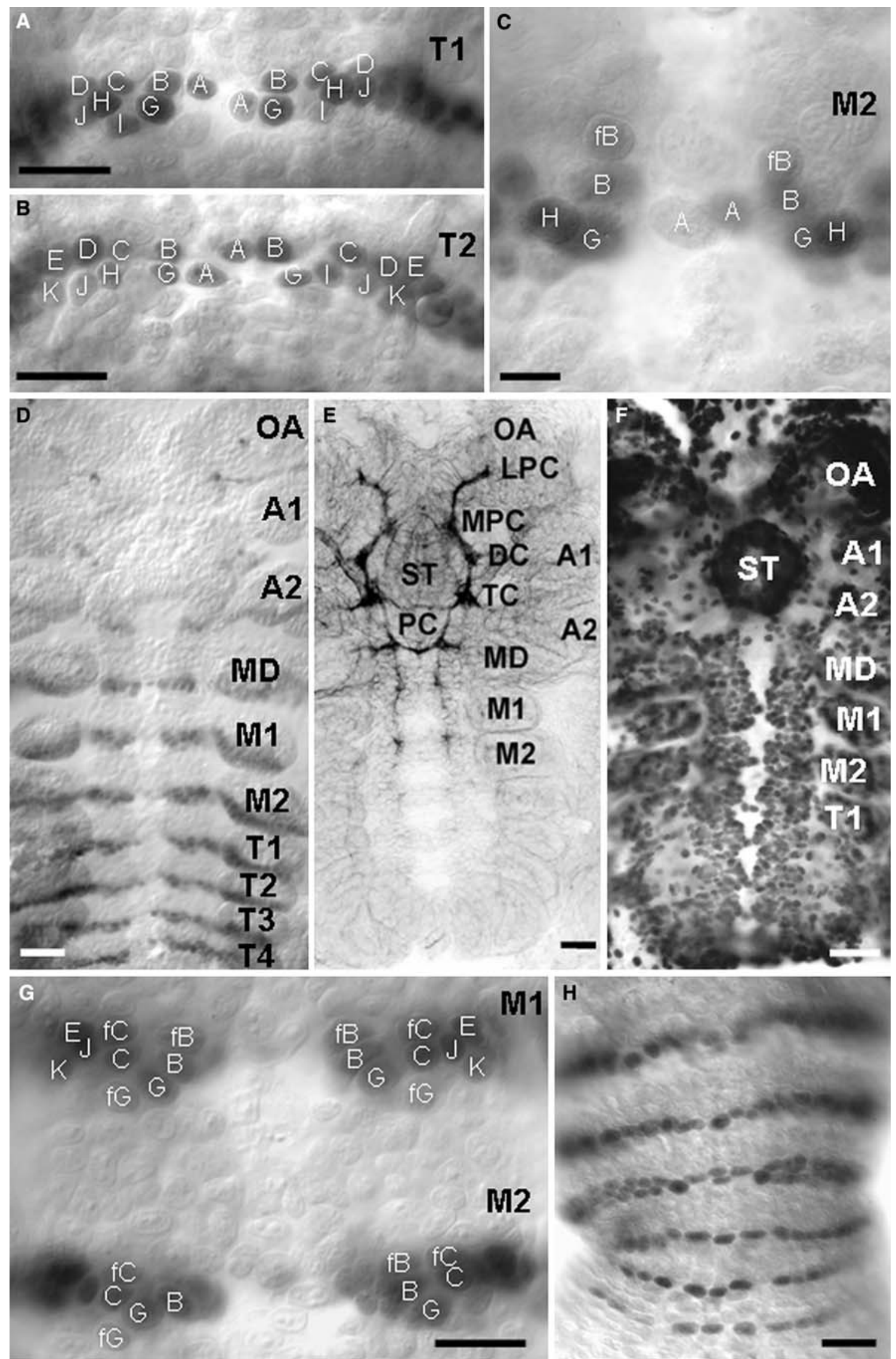


4 Fig. 7 Details of En-li+ cells in dissected embryos from E39 to E40\%. a-c En expression in thoracomere one (a) and two (b) and a different focus level of the maxilla two neuromere (c) of the late E39\% embryo shown in Fig. 9 h-k. d En-li+ immunoreactivity in an embryo at E40\%. e Phalloidin histochemistry to label actin reveals the axonal architecture of the embryonic nervous system at E42\%. Note that in addition to the brain the axonal scaffold of the maxilla one and two neuromeres has emerged (modified from Vilpoux et al. 2006). f Labelling with the in vivo mitosis marker bromodeoxyuridine reveals that at $\mathrm{E} 42 \%$ there is still a high level of mitotic activity throughout the entire embryo including the brain, stomodaeum, limb anlagen and the developing ventral nerve cord. $g$ Maxilla one and two neuromeres of the specimen shown in $\mathbf{d}$ in more detail. Letters label individually identified cells (compare Fig. 16). Note that cells A are not in focus. $\mathbf{h}$ An example for the En expression in the pleon of an embryo at E40\% (ventral view). Abbreviations: $A 1, A 2$ Antenna one and two; $M D$ mandible segment; $M 1, M 2$ maxilla one and two segments; $O A$ optic anlagen; ST stomodaeum; $T 1$ thoracomere one; letters label individually identified cells (compare Fig. 16). Scale bars $\mathbf{a}-\mathbf{b}, \mathbf{g}, \mathbf{h} 25 \mu \mathrm{m}$, c $10 \mu \mathrm{m}, \mathbf{d}-\mathbf{f} 50 \mu \mathrm{m}$

trend persists into E46\% when only between one and three "large" cells per hemineuromere remain En-li+ (Fig. 4a, b) and the majority of En-li+ cells fall into the "small" size category (Fig. S2). "Large" En expressing cells are not present any longer after E60\% (Fig. 11, S4).

Among the "small" cells are a population of clearly identifiable, medially situated cells that appear at E42\% (Fig. 3c, d) and that considering their position show some resemblance to "median neuroblast progeny" (MP) as is present in other arthropods. This type of cell has been described for grasshoppers (Condron et al. 1994), the amphipod crustaceans Orchestia cavimana (Gerberding and Scholtz 1999) and Parhyale hawaiensis (Browne et al. 2005), and the crayfish Procambarus clarkii (DumanScheel and Patel 1999; the median neuroblast itself is not En-li+ in these species). Towards E46\% (Figs. 4, 9) and E50\% (Fig. S4) the number of median neuroblast progeny increases, the cells are strongly labelled and in some preparations they were arranged in a conspicuous quartet pattern (Fig. 4C, 10H). At E46\% two other types of cells with a certain resemblance to counterparts previously described in a crayfish, and an amphipod (Duman-Scheel and Patel 1999; Browne et al. 2005) can be identified individually, the dorsally located EC cells and the ventrally located IC cells (Fig. 4a, b). The expression strength of Engrailed-like immunoreactivity of these cells increases during subsequent embryogenesis and similar to the median neuroblast progeny they can be reliably identified up into the last embryonic stage that we analysed, E65\% (Figs. 4, 9, 10, 11, S4). At E52\% conspicuous strings of En-li+ ventral cells that stretch along the midline appear in addition to the median blast progeny (Fig. 10g).

In addition to this set of medially arranged neurons (MC; Fig. S4A) that comprises the dorsal EC cells, the ventral IC cells and in between the median neuroblast

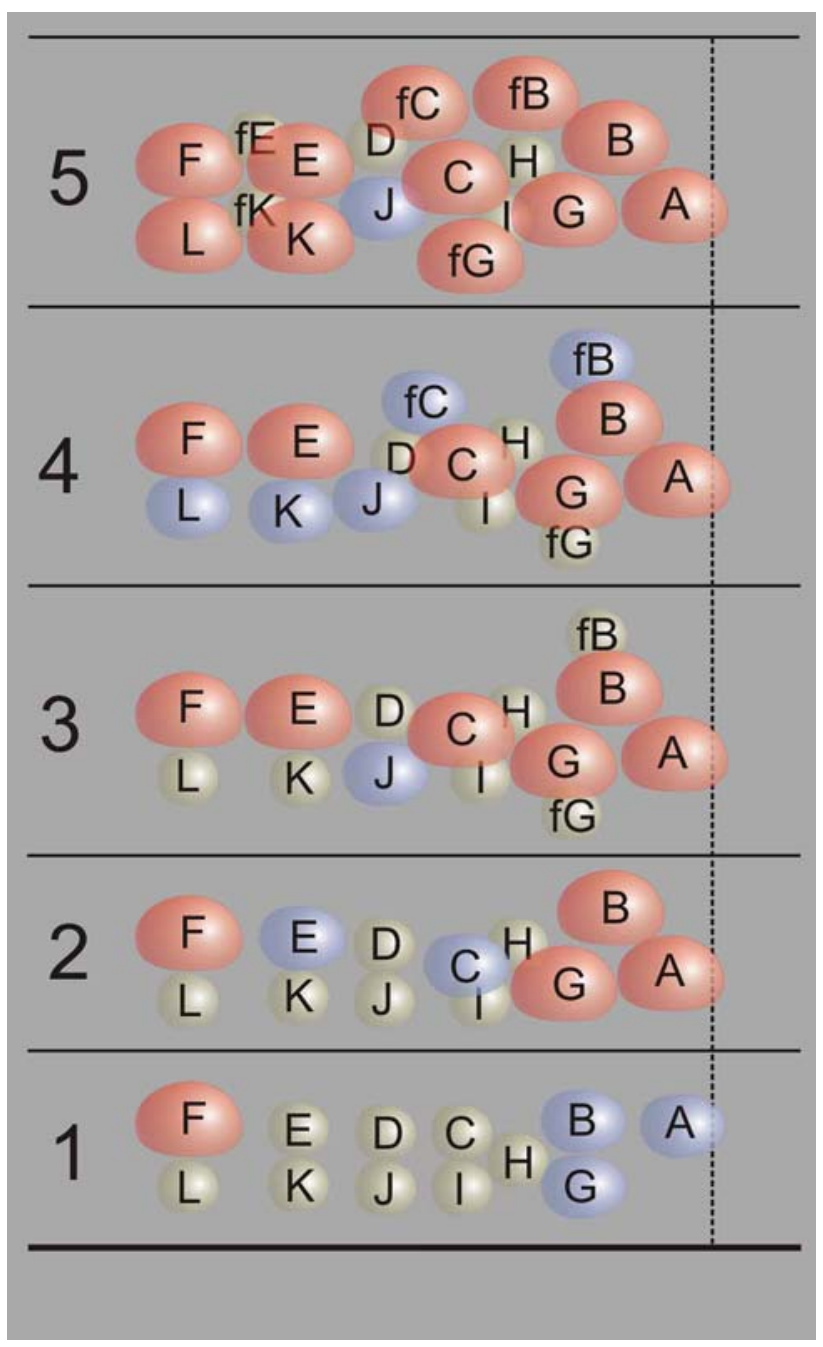

Fig. 8 Schematic overview over the embryonic emergence of En-li+ cells in the ventral neuroectoderm of the Marbled Crayfish representing the neuromeres of maxilla one to thorax one. The arrangement of En-li+ cells during earlier stages of segmentation in crayfish was analysed by Patel et al. (1989b) to whose study our report connects. The left half of the germ band is shown; the vertical line indicates the midline. Only those cells were charted that considering their position were clearly localized medially within the neuroectoderm whereas more lateral cells that were part of the developing limb buds were omitted. The emergence of these cells is a continuous process so that our subdivision into five stages is only for the sake of convenience. We failed to analyse the pattern of En-li+ cells in subsequent developmental stages due to the ever increasing number of cells. The cells were arbitrarily labelled in two rows stretching from right to left. Red large cells, blue intermediate cells, green small cells (compare Fig. 4d)

progeny (MP; Fig. S4B), three-dimensional confocal laserscan images of E50\% embryos show a lateral cluster of En-li+ cells (LC) that are arranged in an arc that dorsally stretches around the sides of the developing ganglia (Fig. S4A). At E52\% both, the median cell group (MC) and the lateral arc cells (LA) are strongly labelled (Fig. S4C). 

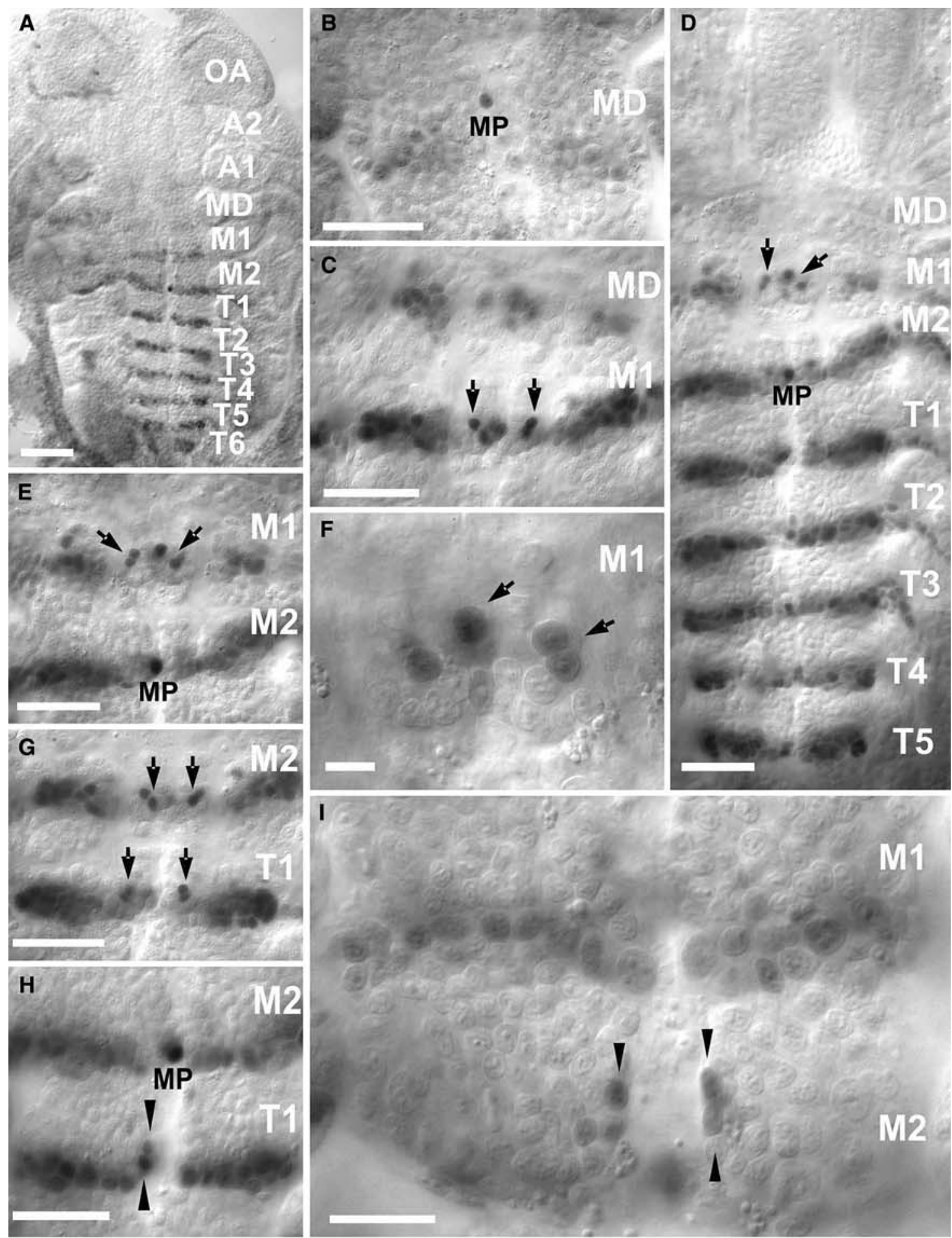

M1
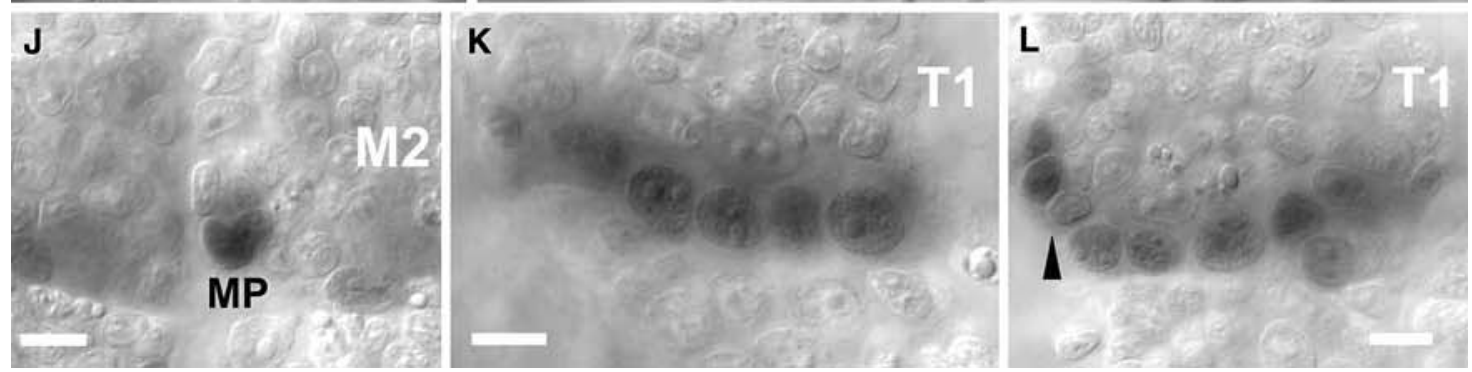
Fig. 9 En-li+ immunoreactivity in an E46\% embryo. $(\mathbf{a}-\mathbf{h}, \mathbf{j})$ are images from the dorsal side and $\mathbf{i}, \mathbf{k}, \mathbf{l}$ from the ventral side of the dissected embryo. a-d En-li+ immunoreactivity has become much weaker in the mandible neuromere. Only one dorsal cell at the midline of the mandible neuromere is still strongly En positive (b). From the maxilla one neuromere to the thoracomere one the dorsal EC neurons have differentiated (arrows in $\mathbf{d}-\mathbf{g}$ ), as illustrated at a higher magnification for the maxilla one neuromere in $\mathbf{f}$. The median neuroblast progeny $(M P)$ are visible in the maxilla two neuromere in $\mathbf{h}, \mathbf{j}$. On the ventral side of the embryo feebly labelled cells are present as shown in $\mathbf{i}, \mathbf{k}, \mathbf{l}$. $\mathbf{k}$ represents the right, $\mathbf{l}$ the left side of the thoracomere one of the embryo. In addition to one row of clearly labelled En-li+ "large" and "intermediate" cells a few smaller cells are arranged along the midline (arrowheads in $\mathbf{h}, \mathbf{i}, \mathbf{l}$ ). Abbreviations: $M D$ mandible segment; $M 1, M 2$ maxilla one and two segments; T1-5 thoracomere 1-5. Scale bars a $100 \mu \mathrm{m}, \mathbf{b}-\mathbf{e}, \mathbf{g}, \mathbf{h} 50 \mu \mathrm{m}, \mathbf{f}, \mathbf{j}-\mathbf{l} 10 \mu \mathrm{m}$, i $25 \mu \mathrm{m}$

By E60\% the lateral arc has broken up into a ventral, lateral cluster (LC) and a more dorsal cell cluster associated with the connectives (CC; Fig. S4D). Dorsal aspects of an E65\% specimen examined with Normarski optics reveal the longitudinal connectives and the anterior and posterior commissures (Fig. 11e-g). These specimens confirm that the strongly labelled dorsal cell cluster (CC) is closely associated with the connectives. This situation closely resembles that reported from lobster embryos in which this cell cluster was suggested to comprise glial cells (Harzsch et al. 1998; Harzsch 2003b).

Disappearance of Engrailed-like immunoreactivity from the mandibular and maxilla one neuromeres

Beginning at E42\%, the strength of Engrailed-like immunoreactivity in the mandible neuromere becomes weaker. At $\mathrm{E} 46 \%$ this process is so far advanced that the mandible neuromere bears only a few feebly labelled En-li+ cells in addition to one distinctly labelled cell close to the midline (Fig. 9a-d; note that the weakly labelled cells of the mandibular neuromere are not in focus in a and d). During subsequent development, we noticed a further retraction of Engrailed-like immunoreactivity backwards towards the maxilla two neuromere. In E52\% embryos, Engrailed-like immunoreactivity in the mandible has disappeared almost completely and expression in the maxilla one neuromere is diminished, only a few ventral median cells continue to express Engrailed-like immunoreactivity (Fig. 4a, 10a-c, $\mathrm{e}$; note that $\mathrm{a}$ and $\mathrm{b}$ show a different focus level than e). By $\mathrm{E} 65 \%$, the neuronal expression of Engrailed-like proteins in the mandible and the maxilla one neuromeres has disappeared completely whereas expression at the posterior margin of the maxilla two neuromere as well as in the more caudal neuromeres remains stable (Fig. 11e-g). A similar disappearance of labelling in the mandibular and maxilla one neuromeres has been observed in late lobster embryos (Harzsch 2003b).

\section{Discussion}

Engrailed expression during segmentation and neurogenesis: evidence for Engrailed-like immunoreactive neuroblasts in Crustacea?

In crayfish, the asymmetrically dividing ectoteloblasts give off descendant cell rows in an anterior direction which then cleave to generate four regular ectodermal rows designated a, b, c, d (review Dohle et al. 2004). The entire ectodermal row $\mathrm{a}$ as well as some cells in row $\mathrm{b}$ begin to express Engrailed (En; Patel et al. 1989b; Alwes and Scholtz 2006). This En stripe then widens by the recruitment of cells from row b that newly express En and by a series of differential cleavages of the row a cells the progeny of which continue to express En (Patel et al. 1989b; Scholtz et al. 1993, 1994). Scholtz et al. (1993, 1994) as well as Gerberding and Scholtz (1999) have provided detailed maps of ectodermal En-positive cells in an amphipod crustacean embryo from the initial expression during segmentation through to the phase of widening of the stripes (see also Dohle et al. 2004; Ungerer and Scholtz 2007). This pattern conforms with our own findings (maxilla one and two segments) in the Marbled Crayfish (pattern No 1) concerning general aspects such as number and arrangement of cells. Thus, our study connects to and extends those on early ectodermal Engrailed expression in the amphipod (Scholtz et al. 1993, 1994; Gerberding and Scholtz 1999, Wolff and Scholtz 2002, 2006) and crayfish embryos (Patel et al. 1989a, b; Alwes and Scholtz 2006).

Our cell measurements suggest the presence of several distinct classes of En-li+ cells in the fully segmented germ band: a class of "large" cells above ca. $75 \mu^{2}$, a population of "small" cells below $60 \mu \mathrm{m}^{2}$ and possibly a third population of "intermediate" cells in between. In those "early" segments where we measured single or slightly widened En-li+ stripes, their cells fell either into the "small" or "intermediate" population. Subsequently, individual cells from the En-li+ stripes enlarge to match the "large" size class. In the last pattern No 5 that we managed to map in detail, eleven "large" cells are present per hemineuromere. During the progression of development we recorded several new En-li+ cells that were typically closely associated with the "large" cells (fB, fC, $\mathrm{fE}, \mathrm{fG}, \mathrm{fK}$ ) so that we tentatively suggest that these cells may derive by unequal division from the "large" cells. In addition, in pattern No 5 and later stages that we failed to map on the level of individual identified cells several other unidentified En-li+ cells in the "small" and "intermediate" size category were frequently associated with, and located dorsally to, the "large" cells which generally remained ventrally in the most superficial layer of the neuroectoderm. A high level of mitotic activity throughout 


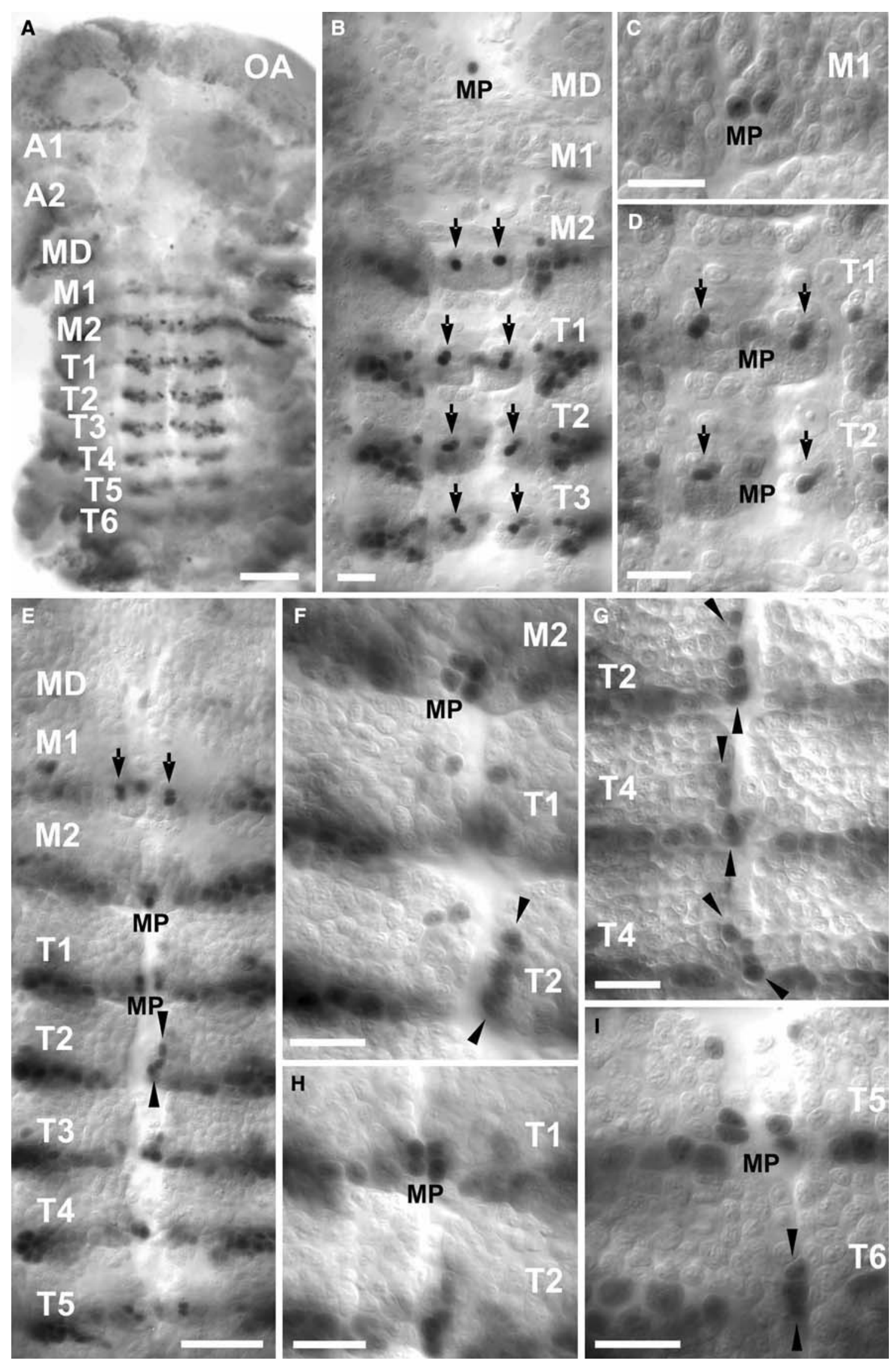


4 Fig. 10 En-li+ immunolocalization in E52\% embryos (all images show the dorsal side of the embryos). Note the further retraction of En-li+ immunoreactivity backwards to the maxilla two neuromere. En-li+ immunoreactivity in the mandible has almost disappeared and expression in the maxilla one neuromere is diminished $(\mathbf{a}, \mathbf{b}, \mathbf{e})$. Only one single median cell in the mandible neuromere still shows En-li+ immunoreactivity $(\mathbf{a}, \mathbf{b})$. In the maxilla one neuromere, only a few ventral median cells continue to show En-li+ immunoreactivity $(\mathbf{c}, \mathbf{e})$. In the other neuromeres, the ventrally located IC cells (arrows in b, d, e), the median neuroblast progeny $(M P)$ and ventral midline cells (arrowheads) are the most prominent En-li+ cells $(\mathbf{d}-\mathbf{i})$. In $\mathbf{d}$ the IC neurons (arrows) of the thoracomeres one and two can be seen whereas in $(\mathbf{e}, \mathbf{f}, \mathbf{h}, \mathbf{i})$ the median neuroblast progeny $(M P)$ is indicated. Images $(\mathbf{g}, \mathbf{i})$ shows the string of En-li+ ventral median cells (arrowheads) that stretch along the midline. Abbreviations: A1, $A 2$ Antenna one and two; $M D$ mandible segment; $M 1, M 2$ maxilla one and two segments; $O A$ optic anlagen; T1-6 thoracomere 1-6. Scale bars a $100 \mu \mathrm{m}, \mathbf{b}, \mathbf{e} 50 \mu \mathrm{m}, \mathbf{c}, \mathbf{d}, \mathbf{f}-\mathbf{h} 25 \mu \mathrm{m}$

the entire neuroectoderm was observed using a mitosis marker which coincided with a rapid increase in numbers of En-li+ cells between E39 and E40\%. BrdU experiments in the ventral nerve cord of late embryos and larvae of selected decapod crustaceans have previously demonstrated the presence of large, asymmetrically dividing neuronal stem cells, the neuroblasts (Harzsch and Dawirs 1994; Harzsch et al. 1998; Harzsch 2001). Neuroblasts undergo repeated unequal divisions to produce ganglion mother cells which they give off mostly into a dorsal direction (reviews Harzsch 2003a, b; Dohle et al. 2004; Whitington 2004). We suggest that some or all "large" Enli+ cells that we encountered in the present study are neuroectodermal cells in the progress of developing into neuroblasts. In Crustacea neuroblasts so far have been identified by their unequal mode of division and the association with dorsally located smaller daughter cells. We find that the "large" En-li+ cells show a similar association with dorsal progeny in the later embryonic stages that we examined. Yet, we cannot exclude that some of these cells may be epidermoblasts. Therefore, in the remaining discussion we will henceforth call the "large" En-li+ cells "putative neuroblasts" while keeping in mind that in the beginning, the neuroblasts may generate progeny that will also become neuroblasts or later on can generate both neuronal progeny, and glial progeny.

Crustacean neuroblasts generate daughter cells, the ganglion mother cells, which later divide again to give birth to ganglion cells (neurons; reviews Harzsch 2003a, b; Dohle et al. 2004; Whitington 2004). It was previously believed that ganglion mother cells in malacostracan crustaceans divide only once as they do in insects but direct evidence for this claim was not available. There is evidence now that ganglion mother cells in the embryonic crustacean brain undergo not just one but two or even three divisions (Benton and Beltz 2002). Contrary, a cell lineage analysis in the ventral nerve cord of an amphipod crustacean provided evidence that at least in some thoracic neuromeres of these animals during embryogenesis the ganglion mother cells divide only once as in insects (Ungerer and Scholtz 2007). Whilst in the earliest embryonic stages that we examined $(\mathrm{E} 38 \%, \mathrm{E} 39 \%)$ most of the En-li+ cells in the "small" and "intermediate" population are superficially located and ectodermal, the labelled cells that we observed from E42\% onwards to be located dorsally to the putative neuroblasts deeper within the developing ganglia may represent ganglion mother cells ("intermediate") and neurons/glia ("small").

\section{Engrailed expression in identified cells}

In the Marbled Crayfish, we found En-li+ cells that considering the expression of their biochemical label and their position may be counterparts to the En-li+ IC and EC types of neurons as well as of the median neuroblast progeny (MP) that previously have been described in another crayfish, and two amphipods (Duman-Scheel and Patel 1999; Gerberding and Scholtz 1999; Browne et al. 2005). These studies had suggested a homology of these crustacean neurons with their counterparts in grasshoppers as described by Condron et al. (1994). Our cell size measurement showed the IC, EC, and MP cells to fall into the "small" class of cells which is consistent with the view that this "small" type includes En-li+ neurons but also glial cells. Nevertheless, we have to stress that comparing insect and crustacean neurons based on the expression of one molecular marker does not provide as strong arguments as cell lineage data (Ungerer and Scholtz 2007) or the analysis of axonal morphologies do (e.g. Whitington 1996; Harzsch 2003b, 2004; Whitington 2004, 2007).

We could not establish any lineage relationship between the putative lateral En-li+ neuroblasts and the emerging En-li+ neurons or glial cells. More detailed studies using intracellular labelling techniques will be necessary to gain information on this issue in crayfish. Such analyses that link cell lineage and cell differentiation have been carried out for the median neuroblast and several lateral neuroblasts of an amphipod crustacean (Gerberding and Scholtz 1999, 2001; Ungerer and Scholtz 2007; review Scholtz and Gerberding 2002). These authors analysed the cell division pattern of midline precursor cells in Orchestia cavimana. In this species, within the post-naupliar germ band, a midline precursor cell undergoes two rounds of equal division resulting in the four clones $\mathrm{a}_{0}, \mathrm{~b}_{0}, \mathrm{c}_{0}$ and $\mathrm{d}_{0}$. The cells $a_{0}, b_{0}, c_{0}$ generate glial cells whereas $d_{0}$ is the median neuroblast, some progeny of which differentiates into Enli+ neurons. The median neuroblast of $O$. cavimana generates about ten neurons that can be classified into four classes: a single unpaired interneuron, the axon of which extends in the median connective; a putative motoneuron, 

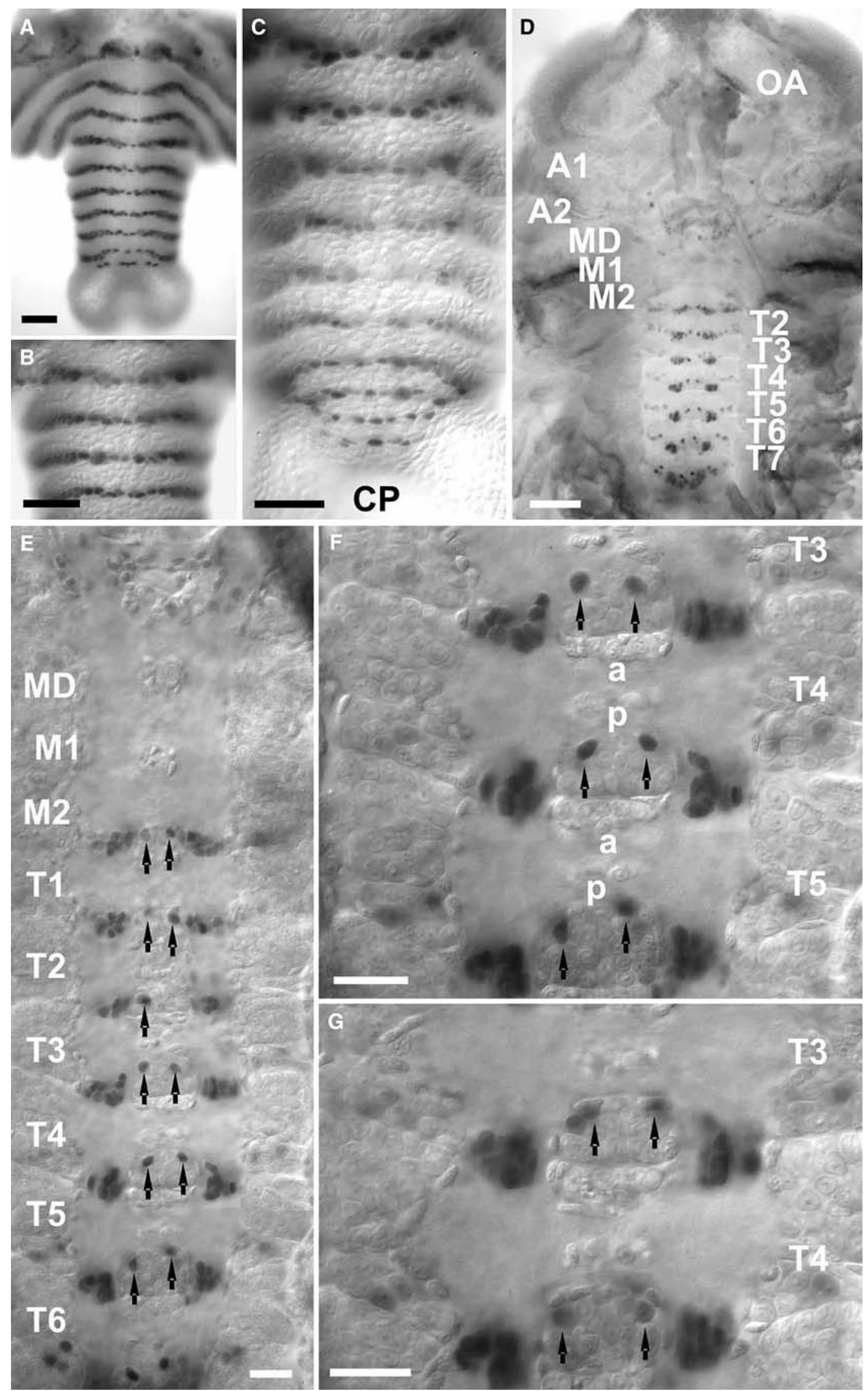
Fig. 11 En-li+ immunolocalization in E52\% and E65\% embryos. ac Segmental En-li+ immunoreactivity in the pleon of an E52\% dissected Marmorkrebs embryo. d Overview of an E65\% embryo, dorsal aspects. The En-li+ immunoreactivity in the mandible and the maxilla one neuromeres has disappeared almost completely. e-g At this stage, in dorsal views the longitudinal connectives and the anterior and posterior commissures (labelled $a$ and $p$ ) can be seen with Normarski optics and the dorsal EC cells can be clearly identified (arrows in $\mathbf{e}-\mathbf{g}$ ). A distinct group of strongly labelled cells (possibly glia) is associated with the connectives. Large En-li+ cells are not present any longer (compare Fig. S4). Abbreviations: A1, A2 Antenna one and two; $a$ anterior commissure; $C O$ connective; $M D$ mandible segment; $M 1, M 2$ maxilla one and two segments; $O A$ optic anlagen; $p$ posterior commissure; $T 1-6$ thoracomeres $1-6$. Scale bars a-c $10 \mu \mathrm{m}, \mathbf{d} 100 \mu \mathrm{m}, \mathbf{e}-\mathbf{g} 25 \mu \mathrm{m}$

the bifurcating axon of which enters the intersegmental nerve; interneurons with axons that bifurcate at the commissures and enter the connectives; and interneurons with axons in the connectives and with dendritic arborisation in the neuropil and commissures of other segments (Gerberding and Scholtz 1999, 2001). The daughter cells of the first division of $\mathrm{a}_{0}$ are Engrailed positive (cells $\mathrm{a}_{0}{ }^{\prime}$ and $\mathrm{a}_{0}{ }^{\prime \prime}$ ) in O. cavimana (whereas the progeny of $\mathrm{b}_{0}$ and $\mathrm{c}_{0}$ are not). These cells seemingly do not divide any further but develop into glial cells (Gerberding and Scholtz 2001). They lose Engrailed expression before the Engrailed positive median neuroblast progeny appears (Gerberding and Scholtz 1999). The Engrailed-like immunoreactive cells $\mathrm{A}$ on both sides of the midline in Marbled Crayfish embryos are in comparable positions as the O. cavimana En-li+ midline cells $\mathrm{a}_{0}{ }^{\prime}$ and $\mathrm{a}_{0}^{\prime \prime}$. Although the left and right A cells are among the first to enlarge into the putative neuroblast size class (E38\%), we never observed any progeny associated with them and their Engrailed-like immunoreactivity fades quite soon (E42\%), similar to the amphipod cells $\mathrm{a}_{0}^{\prime}$ and $\mathrm{a}_{0}{ }^{\prime \prime}$. Tracer injections into these cells may reveal additional similarities or differences to the amphipod midline cells.

Acknowledgments The 4D9 anti-En/invected monoclonal antibody developed by Corey Goodman (University of California, Berkeley, Department of Molecular and Cell Biology, 519 Life Sciences Addition, Berkeley, CA 94720) was obtained from the Developmental Studies Hybridoma Bank developed under the auspices of the NICHD and maintained by The University of Iowa, Department of Biological Sciences, Iowa City, IA 52242. This study was supported by DFG grant HA 2540/5. S. H. was a Heisenberg Fellow of the DFG during the experimental phase of this project. The Max Planck Gesellschaft supported S. H. and S. B. K. during the final preparation of the manuscript.

Open Access This article is distributed under the terms of the Creative Commons Attribution Noncommercial License which permits any noncommercial use, distribution, and reproduction in any medium, provided the original author(s) and source are credited.

\section{References}

Abzhanov A, Kaufman TC (2000) Evolution of distinct expression patterns for En paralogues in higher crustaceans (Malacostraca). Dev Genes Evol 210:493-506. doi:10.1007/s004270000090

Alwes F, Scholtz G (2006) Stages and other aspects of the embryology of the parthenogenetic Marmorkrebs (Decapoda, Reptantia, Astacida). Dev Genes Evol 216:169-184. doi: 10.1007/s00427-005-0041-8

Benton JL, Beltz BS (2002) Patterns of neurogenesis in the midbrain of embryonic lobsters differ from proliferation in the insect and the crustacean ventral nerve cord. J Neurobiol 53:57-67. doi: $10.1002 /$ neu. 10110

Booker R, Truman J (1987) Postembryonic neurogenesis in the CNS of the tobacco hornworm, Manduca sexta. I. Neuroblast arrays and the fate of their progeny during metamorphosis. J Comp Neurol 255:548-559. doi:10.1002/cne.902550407

Booker R, Babashak J, Kim J (1996) Postembryonic neurogenesis in the central nervous system of the tobacco hornworm, Manduca sexta. III. Spatial and temporal patterns of proliferationl. J Neurosci 29:233-248

Bossing T, Udolph G, Doe CQ, Technau GM (1996) The embryonic central nervous system lineages of Drosophila melanogaster. I. Neuroblast lineages derived from the ventral half of the neuroectoderm. Dev Biol 179:41-64. doi:10.1006/dbio.1996. 0240

Breidbach O, Urbach R (1996) Embryonic and postembryonic development of serial homologous neurons in the subesophageal ganglion of Tenebrio molitor (Insecta: Coleoptera). Microsc Res Tech 35:180-200. doi:10.1002/(SICI)1097-0029(19961015)35:3 $<180:$ :AID-JEMT2>3.0.CO;2-S

Broadus J, Skeath JB, Spana EP, Bossing T, Technau G, Doe CQ (1995) New neuroblast markers and the origin of the aCC/pCC neurons in the Drosophila central nervous system. Mech Dev 53:393-402. doi:10.1016/0925-4773(95)00454-8

Browne W, Price A, Gerberding M, Patel N (2005) Stages of embryonic development in the amphipod crustacean, Parhyale hawaiensis. Genesis 42:124-149. doi:10.1002/gene.20145

Campos-Ortega JA, Hartenstein V (1997) The embryonic development of Drosophila melanogaster. Springer, Berlin, p 405

Condron GB, Patel NH, Zinn K (1994) Engrailed controls glial/ neuronal cell fate decisions at the midline of the central nervous system. Neuron 13:541-554. doi:10.1016/0896-6273(94) 90024-8

Doe CQ (1992) Molecular markers for identified neuroblasts and ganglion mother cells in the Drosophila central nervous system. Development 116(4):855-863

Doe CQ, Skeath JB (1996) Neurogenesis in the insect central nervous system. Curr Opin Neurobiol 6:18-24. doi:10.1016/S0959-4388 (96)80004-3

Doe CQ, Technau GM (1993) Identification and cell lineage of individual neural precursors in the Drosophila CNS. Trends Neurosci 16:510-514. doi:10.1016/0166-2236(93)90195-R

Doe CQ, Fuerstenberg S, Peng C-Y (1998) Neural stem cells: from fly to vertebrates. J Neurobiol 36:111-127. doi:10.1002/(SICI)10974695(199808)36:2<111::AID-NEU2>3.0.CO;2-4

Dohle W (1970) Die Bildung und Differenzierung des postnauplialen Keimstreifens von Diastylis rathkei (Crustacea, Cumacea). 1. Die Bildung der Teloblasten und ihrer Derivate. Z Morphol Tiere 67:307-392. doi:10.1007/BF00277503

Dohle W (1972) Über die Bildung und Differnzierung des postnauplialen Keimstreifens von Leptochelia spec. (Crustacea, Tanaidacea). Zool Jb Anat 89:503-566 
Dohle W, Scholtz G (1988) Clonal analysis of the crustacean segment: the discordance between genealogical and segmental borders. Dev Suppl 104:147-160

Dohle W, Scholtz G (1997) How far does cell lineage influence cell fate specification in crustacean embryos? Cell Dev Biol 8:379390. doi:10.1006/scdb.1997.0162

Dohle W, Gerberding M, Hejnol A, Scholtz G (2004) Cell lineage, segment differentiation, and gene expression in crustaceans. In: Scholtz G (ed) Evolutionary developmental biology of Crustacea, Crustacean issues, vol 15. A.A. Balkema, Lisse, pp 135-167

Duman-Scheel M, Patel NH (1999) Analysis of molecular marker expression reveals neuronal homology in distantly related arthropods. Development 126:2327-2334

Gerberding M, Scholtz G (1999) Cell lineage of the midline cells in the amphipod crustacean Orchestia cavimana (Crustacea, Malacostraca) during formation and separation of the germ band. Dev Genes Evol 209:91-102. doi:10.1007/s004270050231

Gerberding M, Scholtz G (2001) Neurons and glia in the midline of the higher crustacean Orchestia cavimana are generated via an invariant cell lineage that comprises a median neuroblast and glial progenitors. Dev Biol 235:397-409. doi:10.1006/dbio.2001. 0302

Goodman CS, Doe CQ (1993) Embryonic development of the Drosophila central nervous system. In: Bate M, Martinez-Arias A (eds) The development of Drosophila melanogaster. Cold Spring Harbor Laboratory Press, Cold Spring Harbor, pp 11311207

Harzsch S (2001) Neurogenesis in the crustacean ventral nerve cord: homology of neuronal stem cells in Malacostraca and Branchiopoda? Evol Dev 3:154-169. doi:10.1046/j.1525-142x.2001. 003003154.x

Harzsch S (2003a) Ontogeny of the ventral nerve cord in malacostracan crustaceans: a common plan for neuronal development in Crustacea and Hexapoda? Arthropod Struct Dev 32:17-38. doi: 10.1016/S1467-8039(03)00008-2

Harzsch S (2003b) Evolution of identified arthropod neurons: the serotonergic system in relation to En-expressing cells in the embryonic ventral nerve cord of the American lobster Homarus americanus Milne Edwards, 1873 (Malacostraca, Pleocyemata, Homarida). Dev Biol 258:44-56. doi:10.1016/S0012-1606(03) 00113-1

Harzsch S (2004) Phylogenetic comparison of serotonin-immunoreactive neurons in representatives of the Chilopoda, Diplopoda and Chelicerata: implications for arthropod relationships. J Morphol 259:198-213. doi:10.1002/jmor.10178

Harzsch S, Dawirs RR (1994) Neurogenesis in larval stages of the spider crab Hyas araneus (Decapoda, Brachyura): proliferation of neuroblasts in the ventral nerve cord. Rouxs Arch Dev Biol 204:93-100. doi:10.1007/BF00361103

Harzsch S, Miller J, Benton J, Dawirs R, Beltz B (1998) Development of the thoracic neuromeres in two crustaceans with different styles of metamorphic development. J Exp Biol 210:2465-2479

Martin P, Kohlmann K, Scholtz G (2007) The parthenogenetic Marmorkrebs (Marbled Crayfish) produces genetically uniform offspring. Naturwissenschaften. doi:10.1007/s00114-007-0260-0

Matsuzaki F (2000) Asymmetric division of Drosophila neural stem cells: a basis for neural diversity. Curr Opin Neurobiol 10:38-44. doi:10.1016/S0959-4388(99)00052-5

Patel NH (1994) The evolution of arthropod segmentation: insights from comparisons of gene expression patterns. Development Supplement:201-207

Patel NH, Martin-Blanco E, Coleman KG, Poole SJ, Ellis MC, Kornberg TB, Goodman CS (1989a) Expression of En proteins in arthropods, annelids, and chordates. Cell 58:955-968. doi: 10.1016/0092-8674(89)90947-1
Patel NH, Kornberg TB, Goodman CS (1989b) Expression of En during segmentation in grasshopper and crayfish. Development 107:201-212

Polanska MA, Yasuda A, Harzsch S (2007) Immunolocalization of SIFamide in the medial brain and optic neuropils of the Marbled Crayfish. Cell Tissue Res 330:331-344. doi:10.1007/s00441007-0473-8

Rieger V, Harzsch S (2008) Embryonic development of the histaminergic system in the ventral nerve cord of the Marbled Crayfish (Marmorkrebs). Tissue Cell 40:113-126. doi:10.1016/j.tice.2007. 10.004

Schmidt H, Rickert C, Bossing T, Vef O, Urban J, Technau GM (1997) The embryonic central nervous system lineages of Drosophila melanogaster. II. Neuroblast lineages derived from the dorsal part of the neuroectoderm. Dev Biol 189:186-204. doi:10.1006/dbio. 1997.8660

Scholtz G (1990) The formation, differentiation and segmentation of the post-neupliar germ band of the amphipod Gammarus pulex L. (Crustacea, Malacostraca, Peracarida). Proc R Soc Lond B Biol Sci 239:163-211. doi:10.1098/rspb.1990.0013

Scholtz G (1992) Cell lineage studies in the crayfish Cherax destructor (Crustacea, Decapoda): germ band formation, segmentation, and early neurogenesis. Rouxs Arch Dev Biol 202:36-48. doi:10.1007/BF00364595

Scholtz G (1995) Expression of the En gene reveals nine putative segment-anlagen in the embryonic pleon of the freshwater crayfish Cherax destructor (Crustacea, Malacostraca, Decapoda). Biol Bull 188:157-165. doi:10.2307/1542081

Scholtz G (1997) 24 Cleavage, germ band formation and head segmentation: the ground pattern of the Euarthropoda. In: Fortey TRH (ed) Arthropod relationships. The systematics association special volume series 55. Chapman \& Hall, London, pp $317-$ 332

Scholtz G (2001) Evolution of developmental patterns in arthropods-the contribution of gene expression to morphology and phylogenetics. Zoology 103:99-111

Scholtz G, Dohle W (1996) Cell lineage and cell fate in crustacean embryos-a comparative approach. Int J Dev Biol 37:211-220

Scholtz G, Gerberding M (2002) Cell lineage of crustacean neuroblasts. In: Wiese $\mathrm{K}$ (ed) The Crustacean nervous system. Springer, Berlin, pp 406-416

Scholtz G, Dohle W, Sandeman RE (1993) Expression of En can be lost and regained in cells of one clone in crustacean embryos. Int J Dev Biol 37:299-304

Scholtz G, Patel NH, Dohle W (1994) Serially homologous En stripes are generated via different cell lineages in the germ band of amphipod crustaceans (Malacostraca, Peracarida). Int J Dev Biol $38: 471-478$

Scholtz G, Braband A, Tolley L, Reimann A, Mittmann B, Lukhaup C, Steuerwald F, Vogt G (2003) Parthenogenesis in an outsider crayfish. Nature 421:806. doi:10.1038/421806a

Seitz R, Vilpoux K, Hopp U, Harzsch S, Maier G (2005) Ontogeny of the Marmorkrebs (Marbled Crayfish): a parthenogenetic crayfish with unknown origin and phylogenetic position. J Exp Zool 303A:393-405. doi:10.1002/jez.a.143

Sintoni S, Fabritius-Vilpoux K, Harzsch S (2007) The Engrailedexpressing secondary head spots in the embryonic crayfish brain: examples for a group of homologous neurons in Crustacea and Hexapoda? Dev Genes Evol 217:791-799. doi:10.1007/s00427007-0189-5

Skeath JB (1999) At the nexus between pattern formation and celltype specification: the generation of individual neuroblast fates in the Drosophila embryonic nervous system. Bioessays 21:922931. doi:10.1002/(SICI)1521-1878(199911)21:11<922::AIDBIES4>3.0.CO;2-T 
Skeath JB, Thor S (2003) Genetic control of Drosophila nerve cord development. Curr Opin Neurobiol 13:8-15. doi:10.1016/S09594388(03)00007-2

Sullivan JM, Macmillan DL (2001) Embryonic and postembryonic neurogenesis in the ventral nerve cord of the freshwater crayfish Cherax destructor. J Exp Zool 290:49-60. doi:10.1002/jez.1035

Technau GM, Berger C, Urbach R (2006) Generation of cell diversity and segmental pattern in the embryonic central nervous system of Drosophila. Dev Dyn 235:861-869. doi:10.1002/dvdy.20566

Truman JW, Ball EE (1998) Patterns of embryonic neurogenesis in a primitive wingless insect, the silverfish, Ctenolepisma longicaudata: comparison with those seen in flying insects. Dev Genes Evol 208:357-368. doi:10.1007/s004270050192

Ungerer P, Scholtz G (2007) Filling the gap between identified neuroblasts and neurons in crustaceans adds new support for Tetraconata. Proc R Soc Lond B Biol Sci. doi:10.1098/rspb. 2007.1391

Urbach R, Technau GM (2003) Early steps in building the insect brain: neuroblast formation and segmental patterning in the developing brain of different insect species. Arthropod Struct Dev 32:103-124. doi:10.1016/S1467-8039(03)00042-2

Urbach R, Technau GM, Breidbach O (2003) Spatial and temporal pattern of neuroblasts, proliferation, and Engrailed expression during early brain development in Tenebrio molitor L. (Coleoptera). Arthropod Struct Dev 32:125-140. doi:10.1016/S14678039(03)00043-4

Urban J, Technau GM (1997) Cell lineage and cell fate specification in the embryonic CNS of Drosophila. Cell Dev Biol 8:391-400. doi:10.1006/scdb.1997.0163

Vilpoux K, Sandeman R, Harzsch S (2006) Early embryonic development of the central nervous system in the Australian crayfish and the Marbled Crayfish (Marmorkrebs). Dev Genes Evol 216:209-223. doi:10.1007/s00427-005-0055-2
Vogt G, Tolley L (2004) Brood care in freshwater crayfish and relationship with the offspring's sensory deficiencies. J Morphol 262:566-582. doi:10.1002/jmor.10169

Vogt G, Tolley L, Scholtz G (2004) Life stages and reproductive components of the Marmorkrebs (Marbled Crayfish), the first parthenogenetic decapod crustacean. J Morphol 261:286-311. doi:10.1002/jmor.10250

Vogt G, Huber M, Thiemann M, van den Boogaart G, Schmitz OJ, Schubart CD (2008) Production of different phenotypes from the same genotype in the same environmet by developmental variation. J Exp Biol 211:510-523. doi:10.1242/jeb.008755

Whitington PM (1996) Evolution of neuronal development in arthropods. Semin Cell Dev Biol 7:605-614. doi:10.1006/scdb. 1996.0074

Whitington PM (2004) The development of the crustacean nervous system. In: Scholtz, G (ed) Evolutionary developmental biology of Crustacea, Crustacean issues, vol 15. Balkema A.A., Lisse, pp 135-167

Whitington PM (2007) The evolution of arthropod nervous systems: insights from neural development in the Onychophora and Myriapoda. In: Strausfeld NJ (ed) Evolution of nervous systems in invertebrates, vol 2. Series: Kaas JH (Ed.-in-chief), Evolution of nervous systems: a comprehensive reference. Elsevier, New York, pp 317-336

Wolff C, Scholtz G (2002) Cell lineage, axis formation, and the origin of germ layers in the amphipod crustacean Orchestia cavimana. Dev Biol 250:44-58. doi:10.1006/dbio.2002.0789

Wolff C, Scholtz G (2006) Cell lineage analysis of the mandibular segment of the amphipod crustacean Orchestia cavimana reveals that the crustacean paragnaths are sternal outgrowths and not limbs. Front Zool 3:19. doi:10.1186/1742-9994-3-19 